\title{
Bank competition, crisis and risk-taking: Evidence from emerging markets in Asia
}

\author{
Wahyoe Soedarmono ${ }^{1}$, Fouad Machrouh ${ }^{2}$, Amine Tarazi $^{3, *}$, a \\ ${ }^{1}$ World Bank, EASPR, Jakarta, Indonesia \\ ${ }^{2}$ Institut Supérieur de Commerce et d'Administration des Entreprises, Casablanca, Morocco \\ ${ }^{3}$ Université de Limoges, LAPE, Limoges, France
}

\begin{abstract}
This paper investigates the impact on financial stability of bank competition in emerging markets by taking into account crisis periods. Based on a broad set of commercial banks in Asia over the 1994-2009 period, the empirical results indicate that a higher degree of market power in the banking market is associated with higher capital ratios, higher income volatility and higher insolvency risk of banks. In general, although banks in less competitive markets hold more capital, the levels of capitalization are not high enough to offset the impact on default risk of higher risk taking. Nevertheless, during crisis periods, specifically the 1997 Asian crisis that has directly affected Asian banks, market power in banking has a stabilizing impact. A closer investigation however shows that such findings only hold for countries with a smaller size of the largest banks, suggesting that the impact of bank competition is conditional on the extent to which the banking industry may benefit from too-big-to-fail subsidies. Overall, this paper has policy implications for bank consolidation policies and the role of the lender of last resort.
\end{abstract}

JEL Classification: G21, G28

Keywords: bank competition, moral hazard, financial crisis, Asia

*Coresponding author. Tel: +33-555-14-92-05

a E-mail addresses: wsoedarmono@worldbank.org, fmachrouh@groupeiscae.ma, amine.tarazi@unilim.fr. The contents of this paper are the sole responsibility of the author and can under no circumstances be regarded as reflected the position of the World Bank, its executive directors or countries they represent. 


\title{
Bank competition, crisis and risk-taking: Evidence from emerging markets in Asia
}

\begin{abstract}
This paper investigates the impact on financial stability of bank competition in emerging markets by taking into account crisis periods. Based on a broad set of commercial banks in Asia over the 1994-2009 period, the empirical results indicate that a higher degree of market power in the banking market is associated with higher capital ratios, higher income volatility and higher insolvency risk of banks. In general, although banks in less competitive markets hold more capital, the levels of capitalization are not high enough to offset the impact on default risk of higher risk taking. Nevertheless, during crisis periods, specifically the 1997 Asian crisis that has directly affected Asian banks, market power in banking has a stabilizing impact. A closer investigation however shows that such findings only hold for countries with a smaller size of the largest banks, suggesting that the impact of bank competition is conditional on the extent to which the banking industry may benefit from too-big-to-fail subsidies. Overall, this paper has policy implications for bank consolidation policies and the role of the lender of last resort.
\end{abstract}

JEL Classification: G21, G28

Keywords: bank competition, moral hazard, financial crisis, Asia 


\section{Introduction}

Since the end of the eighties, financial liberalization aiming to enhance financial sector competition has raised concerns for both researchers and policy makers. In countries with bank-based financial systems, financial liberalization is expected to create more efficient banking markets with lower cost of borrowing for entrepreneurs. Nevertheless, the externalities stemming from an increase in bank competition remain an open question and the occurrence of banking crises in both developing and developed countries over the last three decades has cast doubts on the role of competition in banking. Consequently, the relationship between bank competition and stability remains a widely debated and controversial issue.

This paper aims to revisit and extend the nexus between bank competition and stability, particularly from the perspective of emerging economies with bank-based financial systems that have experienced financial crises. Indeed, a great number of studies have extensively examined the link between competition and risk in banking, but only few works have been dedicated to emerging economies. Furthermore, to our knowledge no study has investigated the impact of financial crises on the link between competition and stability in banking.

The occurrence of financial crises is an important dimension in the competitionstability nexus in banking because crises could directly modify market competitiveness as well as bank behavior in terms of risk taking. Financial crises have also spawned several banking reforms such as capitalizations and consolidations that might in turn alter the degree of competition and moral hazard in banking. Therefore, assessing the link between competition and the risk behavior of banks should take crises into account to control for various factors that might affect the link.

For such purposes, this paper focuses on the Asian banking industry for several reasons. First, Asian countries have undergone dramatic changes from expansionary financial 
liberalization in 1980s to a severe crisis in 1997 and again, have experienced rapid growth of financial globalization in the $21^{\text {st }}$ century (Cook, 2009; Moshirian, 2008). Second, banking stability remains an important issue in both academic and policy circles in Asia, as banking is the predominant source of finance for private sector businesses in Asian countries (Adams, 2008). Yet, private sector businesses in Asia also remain vulnerable, where poor accounting standards, non-transparent management practices, and a governance system with weak protections for minority shareholders remain in the post-Asian crisis (Park, 2006). This corporate vulnerability can in turn deteriorate bank stability through risk-shifting mechanisms as highlighted by Stiglitz and Weiss (1981).

Moreover, the characteristics of competition, crises and reforms in Asian banking are particularly relevant for the purpose of our study. The unsupervised financial liberalization of the 1980s has resulted in stronger competition on the credit market, particularly in real estate markets (Sachs and Woo, 2000). This in turn was perceived as the origin of the 1997 Asian crisis. In response to the 1997 Asian crisis, financial reforms in the form of bank capitalizations and consolidations that might affect bank competition have also been widely implemented ${ }^{1}$.

With regards to bank consolidations, Asian countries have shown a remarkable trend. They have experienced a rapid growth of bank mergers and acquisitions (M\&As) with a growth rate reaching 25\% per year as of 2003 (Santoso, 2009). Such consolidations have led to the emergence of large banks and are likely to alter the degree of competition in banking, but whether these developments resulted in higher or lower bank stability remains unexplored, particularly during crisis periods.

In the meantime, bank consolidations could exacerbate "too-big-to-fail" effects, increasing risk-taking incentives through "gamble for resurrection" strategies to exploit state

\footnotetext{
${ }^{1}$ See Williams and Nguyen (2005) and Klingebiel et al (2001) for further discussion on several financial reforms in Asian countries.
} 
bailouts and to transfer losses from shareholders to the taxpayers. Some Asian countries experienced such kinds of bank moral hazard behavior during the 1997 Asian crisis (Cook, 2009). Although bank consolidations exacerbate the "too-big-to-fail" issues in banking, such policies were often followed during crisis periods to restore domestic banks' financial strength. Furthermore, foreign participation in bank consolidations in the post-1997 Asian crisis was also common in Asia. William and Nguyen (2005) point out that the time period following the 1997 Asian crisis was characterized by substantial changes in the Asian banking industry encompassing bank restructuring programs and widened access to foreign ownership. Domanski (2005) further documents that during 2001-2005, Foreign Direct Investment (FDI), particularly cross-border M\&As involving banks in Third World countries, increased significantly to US\$ 67.5 billion (from only US\$ 2.5 billion during 1991-1995). Asia has thus become the second largest recipient of cross-border bank M\&A after Latin America and accounts for 36 percent of total bank M\&A values. Jeon et al. (2011) further document that the average assets held by foreign banks in Asia and Latin America increased from $26 \%$ in 1997 to $38 \%$ after five years. In Asia, such an increase is different from one country to another, where South Korea and Indonesia exhibit the largest foreign participation rate.

On the whole, our focus on the Asian banking industry enables us to investigate important factors affecting the link between bank competition and stability that have not been considered in the previous literature. Specifically, our main goal is to investigate whether the impact of market power in the banking industry on bank risk taking behavior changes during crisis periods and thus, we provide a benchmark for policy makers in emerging economies regarding banking reforms such as consolidations, foreign participations and bank capitalization. In addition, we also investigate whether bank moral hazard stemming from too-big-to-fail policies, particularly during crisis periods, might alter the nexus between competition and stability in banking. 
In this paper, we specifically consider the 1994-2009 period and a broad set of commercial banks in Asian countries that have been directly affected by the 1997 Asian financial crisis. These include Indonesia, Malaysia, Thailand, and South Korea that were severely devastated by the banking crisis, as well as China, India, Hong Kong, Pakistan, Philippines, Sri Lanka, and Vietnam that were less affected. Our sample also covers the 2008 global credit crisis triggered in the US.

Our results indicate that a higher degree of market power in the banking industry is associated with higher bank capital ratios, higher risk taking, but also higher bank insolvency risk. Hence, although banks in less competitive markets hold more capital, the levels of capitalization are not high enough to offset the impact on default risk of higher risk taking. Furthermore, our findings also show that during crisis periods, specifically the 1997 Asian financial crisis that has directly affected Asian banks, higher market power has the opposite effect. In other words, lower competition in the banking industry has a destabilizing effect in general but a stabilizing impact during crisis periods. A closer look shows that our findings are conditional to the extent to which countries are locked in more or less important "too-bigto-fail" policies because of the size of their largest banks.

The rest of this paper is structured as follows. Section 2 provides a literature review on the relationship between bank market power and bank stability. Section 3 describes the data, variables and provides descriptive statistics. Section 4 highlights the econometric specification and methodology used in this paper. Section 5 discusses our empirical findings, while Section 6 provides a broad set of sensitivity analyses. Section 7 concludes the paper.

\section{Literature review and research focus}

The link between bank market power and bank stability has become a lively debate during the last three decades following financial deregulation and crises throughout the world. 
Marcus (1984) is the first to build a theoretical model showing that competition on the deposit market drives banks to undertake risk-taking strategies due to the contraction in banks' franchise value. This view is well-known as the "franchise value" hypothesis.

Broecker (1990) supports the "franchise value" hypothesis by finding a negative relationship between average banks' credit quality and the number of banks on the market. Besanko and Thakor (1993) highlight that a higher degree of bank competition is associated with a decrease in information rents obtained from relationship lending which in turn increases bank risk taking. Matutes and Vives (1996) further show that market power lowers bank default probability, although an imperfect competition framework with product differentiation is taken into account.

Keeley (1990) is the first to show that competition in the U.S banking industry in the aftermath of financial deregulation erodes bank charter value and induces banks to take on more risk. Demsetz et al. (1996) also analyze the U.S banking industry and find that banks with higher market power are the ones with higher solvency ratios and lower asset risk. In a single-country setting, Bofondi and Ghobi (2004) find that the increased number of banks in the Italian banking system worsens the default rate of loans, while Jimenez et al. (2008) shed light on the negative relationship between the Lerner index and risk taking for Spanish banks. In a cross-country setting, Levy-Yeyati and Micco (2007) find a negative impact of competition on bank stability in Latin American countries.

While the empirical literature mainly reports the impact of bank competition on individual bank risk taking, the decline in the franchise value of banks during liberalization periods as a source of banking crisis has also been reported by Stiglitz and Weiss (1981), Taylor (1983), Cho (1986), Fry (1988), Dornbusch and Reynoso (1989), Jensen (1989) and Chang and Velasco (2001). Beck et al. (2006) again emphasize the effect of bank concentration on the probability of banking crises. From 69 countries during the 1980-1997 
period, they find that banking crises are less likely to occur in a more concentrated banking system. In the case of Russian banks, Fungáčová and Weill (2009) find that a higher degree of bank competition is associated with an increase in bank failures. In the case of developing countries over the 1999-2005 period, Ariss (2010) finds that greater bank market power enhances bank stability and profit efficiency, although it also deteriorates cost efficiency.

In spite of a growing literature supporting the "franchise value" hypothesis, Boyd and De Nicolo (2005) propose another view known as the "competition-stability" hypothesis. They show that bank market power in the deposit market induces banks to increase the cost of borrowing for entrepreneurs. Such a strategy can increase entrepreneurial moral hazard to undertake risky projects which in turn increases entrepreneurial default risk. Higher entrepreneurial default risk therefore erodes the solvency of banks through risk-shifting mechanisms emphasized by Stiglitz and Weiss (1981).

Boyd et al. (2006) provide evidence that supports the "competition-stability" hypothesis. For a U.S. and an international bank sample, they show that a higher degree of bank competition is not necessarily associated with an increase in the probability of bank failures. In the case of European banks, Uhde and Heimeshoff (2009) further highlight that bank concentration deteriorates financial stability. This negative effect of bank concentration on stability is more severe in the less developed countries of Eastern Europe. Using a sample of banks located in Southeast Asia, Liu et al. (2011) show that greater bank competition does not necessarily increase bank risk taking.

In the meantime, some studies highlight the role of bank capital requirements as prudential tools that might affect the competition-stability nexus in banking. Using a sample of 543 banks operating in 13 Central and East European (CEE) countries over the 1998-2005 period, Agoraki et al. (2009) find that capital requirements reduce risk in general, but for banks with higher market power this effect is significantly weaker or can be reversed. 
Moreover, using a sample of 421 commercial banks from 61 countries, Behr et al. (2010) also show that, after controlling for financial development, legal system efficiency, and several individual bank and country-specific variables, the effectiveness of capital requirements to reduce bank risk taking only holds in banking markets with a lower degree of concentration. Such evidence reflects that a higher degree of bank concentration has already enabled banks to reinforce their charter value and hence, to increase banks' capital ratios (Berger et al., 2009). Therefore, the reinforcement of non-binding capital requirements in well-capitalized banks can deteriorate bank stability due to a decrease in the monitoring intensity and the amount of capital held by the banks (Blum, 2003).

Although some papers highlight the role of prudential regulations (e.g. bank capital requirements) in the nexus between bank competition and risk, to our best knowledge, only few studies highlight how bank competition affects banks' discretionary behavior in their capital management. More specifically, Schaeck and Cihak (2010) show that banks in a more competitive market tend to hold higher capital ratios as "peer market discipline" tools, while Berger et al. (2009) find the opposite result.

Berger et al. (2009a) highlight that the "franchise value" hypothesis and the “competition-stability" hypothesis need not be opposing propositions. Based on a sample of 8,235 banks in developed countries, their empirical results indicate that a higher degree of bank market power is associated with an increase in non-performing loans, supporting the “competition-stability" hypothesis. On the other hand, a higher degree of bank market power is also associated with a decrease in bank insolvency risk and hence, highlighting the "franchise value" hypothesis. The latter finding is due to an increase in bank capital ratios when bank market power increases.

By considering a sample of Asian banks during the 2001-2007 period, moreover, Soedarmono et al. (2011) show that although banks hold more capital in less competitive 
markets, greater market power is associated with higher instability. But their results also highlight that higher economic growth tends to temper risk taking incentives.

As our study focuses on the Asian banking industry that has experienced a severe financial crisis at least in 1997, we extend the existing literature on the relationships between bank competition, capital ratios and risk by considering the influence of crises. Our work extends Soedarmono et al. (2011) who investigate a close issue by using a sample of banks for the 2001-2007 period which was not affected by financial crises. In this paper, by considering a longer time period (1994-2009), we focus on the risk behavior of banks during the 1997 Asian financial crisis as well as the global crisis of 2008 .

Previous literature on the business cycle theory suggests that during a downturn period due to a financial crisis, banks are likely to become more risk-averse by reducing loan extension and thus by building up capital ratios (Borio et al., 2001; Ayuso et al., 2004; Jokipii and Milne, 2008). Such a situation can reduce bank moral hazard to undertake excessive risk which will in turn reduce the systematic risk exposure of banks. In contrast, Cook (2009) points out that some countries in Asia still suffer from bank moral hazard during the 1997 Asian crisis period. Therefore, the impact of market power on bank risk behavior remains questionable during a financial crisis, because crises are likely to modify the risk behavior of banks. They can either become more risk-averse or follow riskier strategies (moral hazard) to further exploit safety net subsidies.

Further, we also extend the existing literature that considers bank regulation in the competition-stability nexus in banking. In this regard, our paper is the first to examine the role of too-big-to-fail subsidies on the link between bank competition and risk-taking behavior. Considering the influence of too-big-to-fail subsidies is an important dimension to shed light on the role of the lender of last resort, as we investigate the impact of financial crises. 
To this end, our main goal is to closely examine whether financial crises and too-bigto-fail subsidies affect the competition-stability nexus in banking. Our study is thus useful to provide a benchmark for bank consolidation and too-big-to-fail policies that aim to enhance market power in the banking industry.

\section{Data, variables and descriptive statistics}

\subsection{Data}

The data used in this paper are taken from several sources. Bank-level data are retrieved from BankScope Fitch IBCA to construct a sample consisting of an unbalanced panel of annual series for the 1994-2009 period covering the 1997/1998 Asian crisis and the 2008 credit crisis. We also impose some restrictions on our initial bank sample. Following Ariss (2010) we exclude banks with less than three consecutive yearly observations and banks that do not provide information on the main variables we use to calculate the degree of market power in the banking industry, such as interest expenses, loans, or net income.

Following Agusman et al. (2006), Laeven (1999) and Soedarmono et al. (2011) who study Asian banks, we focus only on commercial banks, since commercial banks tend to have more freedom to choose their business mix and face similar restrictions across countries. We therefore end up with 636 commercial banks established in 11 countries in Asia. These include the following countries where the number of banks obtained in each country is shown in parentheses: China (103), Hong Kong (68), India (84), Indonesia (108), Malaysia (63), Pakistan (34), Philippines (39), South Korea (50), Sri Lanka (14), Thailand (40), and Vietnam (33).

Meanwhile, country-level data, such as foreign exchange reserves, real gross domestic product and inflation rate, come from the International Financial Statistics database (IFS) provided by the International Monetary Fund. Country data regarding financial structure come 
from Beck and Demirgüc-Kunt (2009), while data on country governance (governance index) come from Kaufmann et al. (2008). Finally, we also retrieve the economic freedom index provided by Heritage Foundation.

\subsection{Bank competition}

To estimate the degree of competition in the banking industry we use a measure of market power for the banking industry considered as a whole (aggregate index), as in Soedarmono et al. (2011), which is more appropriate than individual bank indices for Asian banking industries characterized by complex ownership structures and pyramids. Hence, we analyze the impact of aggregate indexes of bank market power on individual bank risk taking, insolvency risk and capital ratios. Liu et al. (2011) also use a bank competition measure at the country level to analyze the link between bank competition and risk taking in Southeast Asia.

In this paper, we employ the new industrial organization approach applied to the banking sector as in Uchida and Tsutsui (2005). We hence use panel data techniques to estimate the degree of market power for each period. Such an approach does not require any information on the market structure of each bank and a market equilibrium assumption. Furthermore, this method allows us to determine the degree of market power endogenously and hence, differences in bank business models can be taken into account, e.g. whether banks mainly perform traditional intermediation activities or are more involved in non-interest income activities.

More specifically, we jointly estimate a system of three equations that correspond to a translog cost function, to a bank profit maximization revenue function, and to an inverse loan demand function for each country, as shown in Equation (1). To define output, we follow Brissimis et al. (2008) using total revenue from both interest and non-interest revenue ${ }^{2}$. This

\footnotetext{
${ }^{2}$ We estimate the competition measure as in Soedarmono (2010) and in Soedarmono et al. (2011). Soedarmono (2010) investigates the link between bank competition and economic growth in the Asian context (Finance-
} 
construction allows us to implicitly capture the implications of a different strategy of banks, since they can perform both interest and non-interest income activities for bank profitability, a trend which has been observed in most banking systems around the world.

$$
\begin{aligned}
\ln C_{i t}= & b_{0}+b_{1} \overline{\ln q_{i t}}+\frac{1}{2} b_{2}\left(\overline{\ln q_{i t}}\right)^{2}+b_{3} \overline{\ln d_{i t}}+\frac{1}{2} b_{4}\left(\overline{\ln d_{i t}}\right)^{2}+b_{5} \overline{\ln w_{i t}}+\frac{1}{2} b_{6}\left(\overline{\ln w_{i t}}\right)^{2} \\
& +b_{7}\left(\overline{\ln q_{i t}}\right)\left(\overline{\ln w_{i t}}\right)+b_{8}\left(\overline{\ln q_{i t}}\right)\left(\overline{\ln d_{i t}}\right)+b_{9}\left(\overline{\ln d_{i t}}\right)\left(\overline{\ln w_{i t}}\right)+e_{i t}^{C} \\
R_{i t}= & \frac{\theta_{t}}{\eta_{t}} R_{i t}+r_{i t} q_{i t}+c_{i t}\left(b_{1}+b_{2}\left(\overline{\ln q_{i t}}\right)+b_{7}\left(\overline{\ln w_{i t}}\right)+b_{8}\left(\overline{\ln d_{i t}}\right)\right) \\
& +C_{i t} \frac{q_{i t}}{d_{i t}}\left(b_{3}+b_{4}\left(\overline{\ln d_{i t}}\right)+b_{8}\left(\overline{\ln q_{i t}}\right)+b_{9}\left(\overline{\ln w_{i t}}\right)\right)+e_{i t}^{S} \\
\ln p_{i t}= & g_{0}-(1 / \eta) \ln q_{i t}+g_{1} \ln G D P G_{t}+g_{2} \ln I R_{t}+g_{2} \ln T A_{i t}+e_{i t}^{D}
\end{aligned}
$$

Variables with bars are deviations from their cross-sectional means in each time period to reduce multicollinearity. The degree of competition in each year is given by $\theta_{t} \in[0,1]$ representing the well-known conjectural variations of elasticity of total banking industry outputs with respect to the output of bank $i$. In the case of perfect competition, $\theta_{t}=0$; under pure monopoly, $\theta_{t}=1$; and finally, $\theta_{t}<0$ implies pricing below marginal cost and could result, for example, from a non-optimizing behavior of banks.

Specifically, $C_{i t}$ is measured by total expenses, $q_{i t}$ by total earning assets, $d_{i t}$ by total deposits and short-term funding, $w_{i t}$ by the ratio of operating expenses to total assets, $R_{i t}$ by total revenue, $r_{i t}$ by the ratio of interest expenses to total deposits, $p_{i t}$ by the ratio of total revenue to total earning assets. Meanwhile, $G D P G_{t}, I R_{t}$ and $T A_{i t}$ are factors that affect 
demand, defined as the growth of real gross domestic product (GDP), the short-term interest rate, and bank total assets, respectively ${ }^{3}$.

In the next turn, we perform country-level estimations and specify the Seemingly Unrelated Regression (SUR) method to solve System (1). To estimate $\theta_{t}$ we use annual time dummy variables, while to estimate $\eta$ we use bi-annual time dummy variables (every two years). This is because the values taken by $\eta$ are linearly dependent on the time-specific control variable (GDPG and $I R)$ in the third structural equation of System (1). In the subsequent analyses, $\theta_{t}$ denotes the Lerner index (LERNER) of the banking industry in each country.

In some cases, moreover, we also consider the square term $L E R N E R^{2}$ to capture possible non-linearity effects of market power on capital ratios, risk taking and insolvency risk. In calculating $L E R N E R^{2}$, we set $L E R N E R^{2}$ equal to zero if the value taken by $L E R N E R$ is negative.

\subsection{Dependent and control variables}

In this study, we consider three dependent variables of interest to assess bank stability. These include the ratio of bank capital, a risk taking proxy and an insolvency risk measure. The ratio of bank capital is measured either by the total risk-based capital ratio $(C A R)$ or the ratio of total equity to total assets (EQTA). To measure bank risk taking, we use the standard deviation of profitability measured either by the return on assets (or SDROA) or the return on equity (or SDROE) ${ }^{4}$. Following Agoraki et al. (2009), SDROA and SDROE at time $t$ are both calculated on the basis of observations of $R O A$ and $R O E$, respectively, from time $t$ to $t-2$ (a

\footnotetext{
${ }^{3}$ Following Brissimis et al. (2008), the short-term interest rate can be the interbank rate, the money market rate, etc, depending on data availability in each country. As we estimate the degree of bank competition separately for each country, this procedure is not a potential problem as highlighted by Brissimis et al. (2008).

${ }^{4}$ Return on assets $(R O A)$ is the ratio of net income to total assets, while return on equity $(R O E)$ is the ratio of net income to total equity.
} 
three period-based rolling window). In order to measure bank insolvency risk, moreover, we use two types of Z-score measures based on either $R O A$ or $R O E$ represented by ZROA or ZROE, respectively.

ZROA indicates the number of standard deviations that a bank's $R O A$ has to drop below its expected value before equity is depleted. Thus, a higher ZROA is associated with a decrease in a bank's default probability or bank's insolvency risk. For each bank $i$ and time $t$, ZROA is defined as follows

$$
Z R O A_{i, t}=\frac{\operatorname{ROA}_{i, t}+E Q T A_{i, t}}{S D R O A_{i, t}}
$$

SDROA is calculated on the basis of a three-period rolling window as described above. Likewise, we also consider the Z-score based on the return on average equity (ZROE) to capture bank insolvency risk. ZROE is defined as follows

$$
\mathrm{ZROE}_{i, t}=\frac{1+\mathrm{ROE}_{i, t}}{\operatorname{SDROE} E_{i, t}}
$$

SDROE is also calculated on the basis of a three-period rolling window.

Finally, we also introduce a set of control variables that are bank specific and country specific. For bank-specific control variables, we consider the ratio of total deposits and shortterm funding to total assets $(D E P O)$, the ratio of total loans to total assets $(L O A N)$, the ratio of loan loss provisions to total loans $(L L P)$, the ratio of operating expenses to total assets (OVERHEAD) and the logarithm of bank total assets (SIZE). For country-specific control variables, we incorporate the annual growth rate of foreign exchange reserve (FOREXG), the real gross domestic product growth rate $(G D P G)$ and the inflation rate $(I N F)$.

For an additional analysis, we also include the ratio of the three largest banks' total assets to GDP (TBTS) in some regressions to highlight the influence of too-big-to-fail policies at the country level that might affect bank risk taking behavior. Accordingly, we further incorporate the interaction term between LERNER and TBTS (or LERNER*TBTS) to examine 
the combined effect of market power in banking and too-big-to-fail subsidies provided by the lender of last resort.

\subsection{Descriptive statistics}

In order to eliminate the effects of measurement errors, we eliminate the extreme bank/year values of some variables that exhibit left-skewed and/or right-skewed distributions before we run the regressions. Specifically, we eliminate the $2.5 \%$ highest and/or $2.5 \%$ lowest values of our variables that are left-skewed and/or right-skewed. Such a method which is standard in the literature has an important drawback because it systematically eliminates values that could be of interest, particularly during crisis periods. We therefore carefully check that we only eliminate obvious outliers due to errors in data collection. Furthermore, we only clean some of our variables by using such a procedure: ROE, ZROA, ZROE and OVERHEAD. For ROE, we eliminate both their $2.5 \%$ lowest and $2.5 \%$ highest values, because $R O E$ values initially range from - 301 to 1543 which are not economically plausible values given that $R O E$ is the ratio of net income to total equity ${ }^{5}$. For $Z R O A, Z R O E$ and OVERHEAD, we only eliminate their $2.5 \%$ highest values because these variables only exhibit a right-skewed distribution ${ }^{6}$. In addition, regarding $D E P O$ and $L L P$, we do not impose the similar restrictions applied to ROE, ZROA, ZROE and OVERHEAD. Specifically, we eliminate $D E P O$ and $L L P$ values that are higher than 1 and lower than 0 , since both variables should range from 0 to 1 .

Table 1 reports descriptive statistics on the "clean" variables used in this paper, while Table 2 shows the degree of market power in the banking industry for each country and at

\footnotetext{
${ }^{5}$ To ensure robustness, we also consider a different cut-off in cleaning $R O E$ where we eliminate their $1 \%$ highest and $1 \%$ lowest values. The empirical results remain unaltered.

${ }^{6}$ Again, we also consider a cut-off of $1 \%$ in performing this procedure. The empirical results are also consistent with the case when we use a cut-off of $2.5 \%$.
} 
each time period. Moreover, Table 3 presents the correlation among all the variables used in this study ${ }^{7}$.

In Table 1, we also present three indicators (ECOFREE, RLAW and STOCK) used as instrumental variables for LERNER discussed in the next section. We retrieve the economic freedom index (ECOFREE) from Heritage Foundation, the rule of law index $(R L A W)$ from Kaufman et al. (2008) and the ratio of stock market capitalization to GDP (STOCK) from Beck and Demirgüç-Kunt (2009).

Insert Table 1, Table 2 and Table 3 here

\section{Econometric specification and methodology}

Our analysis departs from Uhde and Heimeshoff (2009) who investigate the link between consolidation and stability in European banking. However, in this paper, we consider the link with market power instead of concentration as in Udhe and Heimeshoff (2009) in order to account for the implications of bank consolidation. This is because bank consolidations are likely to enhance market power and improve efficiency rather than increasing market concentration per se (DeYoung et al., 2009). Kane (2000) also finds that acquiring stockholders in US bank 'megamergers' experienced positive abnormal returns, highlighting that consolidation opens access to greater market power that increases profitability. De Guevara et al. (2005) again document that consolidations drove down European banks' marginal costs faster than output prices, suggesting an increase in European banks' market power after consolidation.

For the sake of consistency with prior literature on the competition-stability nexus in banking (e.g. Schaeck and Cihak, 2010; Uhde and Heimeshoff, 2009), moreover, we employ

\footnotetext{
${ }^{7}$ Performing a variation inflation factor (VIF) test confirms that that multicollinearity is not a major issue (coefficient lower than 10). The VIF test is reported in tables presenting estimation results (from Table 4 to 10).
} 
the Two-Stage Least Squares (2SLS) with fixed effect corrections. By taking into account individual and time fixed effects, we avoid drawbacks due to omitted variables that are bank specific and time specific. In specifying the 2SLS estimations, we incorporate three instrumental variables for LERNER. These variables include the economic freedom index (ECOFREE), the rule of law index $(R L A W)$ and the ratio of stock market capitalization to $\operatorname{GDP}(S T O C K)^{8}$.

In this study, we also consider whether financial crises affect the impact of market power in the banking industry on bank capital ratios, risk taking and insolvency risk. The financial crises taken into account in this study are the 1997 Asian crisis and the 2008 credit crisis. For such a purpose, we consider the 1997-1999 period that stands for the Asian crisis period; and the 2007-2009 period to capture the 2008 credit crisis period. Cook (2009) has emphasized the 1997-1999 period to shed light on the Asian financial crisis. In the meantime, considering the 2007-2009 period to highlight the 2008 crisis is consistent with higher volatility in the spread between the London Inter-Bank Offered Rate (LIBOR) and the Overnight Indexed Swaps rate (OIS) which is considered as a measure of the soundness of the banking system ${ }^{9}$.

In terms of methodology, we proceed in four steps. First, we analyze the impact of market power in the banking industry on bank capital ratios, risk taking and insolvency risk for the whole period of study from 1994 to 2009. Second, we repeat the first step, but we only consider the 1997-1999 period to account for the influence of the 1997 Asian financial crisis. Third, we also repeat the first step, but the estimations are only conducted for the 2007-2009 period to capture the influence of the 2008 credit crisis. Finally, we again repeat these three

\footnotetext{
${ }^{8}$ See Appendix B for further explanation with regards to the use of economic freedom, rule of law and stock market capitalization as instrumental variables for $L E R N E R$.

${ }^{9}$ On August 2007, the LIBOR-OIS spread was around 10 basis points, while on September 2007, the spread rose significantly to 85 basis points that marked the beginning of a crisis period. As of October 10, 2008, the spread rose again to 365 basis points and reached a peak on December 2008, before gradually decreasing in 2009. By the end of 2009, credit risks remain higher than those in August 2007 and hence, 2009 is still considered as part of the 2008 crisis period. See Sengupta and Tam (2008) or Gefang et al. (2011) for further details.
} 
steps by incorporating the interaction term between market power in banking and too-big-tofail subsidies (LERNER*TBTS) as an explanatory variable to examine whether too-big-to-fail policies at the country level might affect the relation between market power and stability in banking.

\section{Empirical results}

We run all our regressions by specifying instrumental variables for market power (LERNER). Table 4 shows that our instrumental variables (ECOFREE, RLAW and STOCK) are significantly linked to the banking industry market power variable (LERNER). Higher bank competition could be driven by better rules of law, a result which is consistent with the view that shareholder protection improves financial globalization which in turn may increase the degree of competition among banks (Moshirian, 2009). On the contrary, we denote that economic freedom (ECOFREE) and stock market capitalization (STOCK) do not necessarily hinder the degree of market power in the banking industry. Specifically, both ECOFREE and STOCK positively affect the degree of market power in the banking industry.

\section{Insert Table 4 here}

\subsection{Overall period}

Table 5 shows the results obtained with 2SLS estimations for the overall period from 1994 to 2009. Regarding bank capitalization as measured by $C A R$ and EQTA, our results indicate a positive impact of market power in banking (LERNER) on bank capital ratios. Although we incorporate the squared term of the market power index (LERNER_SQ), the positive link between $L E R N E R$ and bank capital ratios (CAR and EQTA) is not altered, albeit not significant. These results are consistent with Berger el al. (2009a) who find a positive relationship between bank-level Lerner indexes and the capital ratio. 


\section{Insert Table 5 here}

Considering the link between bank competition and risk taking, we find that market power (LERNER) is positively related to banks' income volatility measures (SDROA and SDROE), while this relationship remains unaltered when we incorporate $L E R N E R \_S Q$ as a control variable. Such relationships thus indicate that market power in the banking industry increases bank risk taking ${ }^{10}$.

With regards to the impact of bank competition on bank insolvency risk, Table 5 shows that higher market power (LERNER) leads to higher bank insolvency risk as measured by ZROA and ZROE. Meanwhile, LERNER_SQ is positively related to ZROE with an inflection point of 0.95 . However, we observe that more than $99 \%$ of the observations are below 0.95 . Thus higher market power (LERNER) leads to higher bank insolvency risk (ZROA and ZROE $)^{11}$.

On the whole, considering the results shown in Table 5, our findings indicate that in less competitive banking markets, although higher capital ratios are expected to lower bank default risk, higher risk taking drives default risk in the opposite direction. Therefore, our results suggest that the increase in capital ratios in less competitive banking markets is not high enough to offset higher bank risk taking and to guarantee bank solvency. Our results also suggest that the self-disciplining factor induced by higher market power is not sufficient to moderate excessive bank risk taking, and to increase bank incentives to hold sufficient capital to ensure bank solvency.

\footnotetext{
${ }^{10}$ To check for robustness, we also calculate respectively SDROA and SDROE on the basis of ROA and ROE, from time $t$ and time $t-1$ (a two period-based rolling window). The estimation results are not altered, and the outputs for these specifications are available from the authors upon request.

${ }^{11}$ To check for robustness, we further employ ZROA based on SDROA which is calculated using observations of $R O A$ at time $t$ and time $t-1$ (a two period-based rolling window). The link between LERNER and ZROA is not altered. Analogically, we also compute $Z R O E$ on the basis of two-period rolling windows to define the standard deviation. The link between LERNER and ZROE is not altered.
} 
Our findings are in line with those of Agusman et al. (2006), where greater charter value in Asian listed banks fails to reduce banks' income volatility. Our findings are also consistent with Liu et al. (2011), where higher bank competition results in higher stability in Southeast Asian banks. Our findings also support Schaeck et al. (2009) who analyze the competition-stability nexus using the Panzar-Rosse approach. Using a sample of both developed and developing countries, including some of the Asian countries used in our study, they show that a more competitive banking market is less prone to a systemic banking crisis and exhibit increased time to crisis.

Conversely, our findings differ from Ariss (2010) who studies developing countries in a cross-country setting, where greater bank market power is found to enhance bank stability. Such differences could be explained by the fact that we use a sample of different countries in our study, or that we focus on a panel data approach that considers time fixed effects. The importance of time-fixed effects in the nexus between bank competition and financial stability is shown in the next section, in which we analyze whether financial crises affect such relationships and hence, can alter our previous findings.

\subsection{Do financial crises matter?}

During a financial crisis that creates an economic downturn, it is perceived that banks tend to reduce loans and build up capital ratios, since capital is expected to buffer against the shocks of the crisis and to increase banks' competitive advantage in a market (Berger and Bouwman, 2009). Higher risk aversion of banks can thus moderate moral hazard in terms of excessive lending. Conversely, Brownbridge and Kirkpatrick (1999) point out that during a crisis, banks could behave imprudently due to a massive decline in bank capital ratios and an increase in maturity mismatch. This is because such situations erode the franchise value of banks encouraging risky or fraudulent behavior. 
As bank franchise values become important during crisis periods, we analyze whether during financial crises, higher market power in the banking industry that facilitates banks to maintain their franchise value is important to moderate bank moral hazard. The financial crises analyzed in this study include the 1997/1998 Asian crisis and the 2008 credit crisis.

In order to investigate the competition-stability nexus in banking during the 1997 Asian crisis, we repeat the estimations conducted in Section 5.1 for the 1997-1999 period. From Table 6, it appears that higher LERNER reduces bank capital ratios as measured by EQTA and CAR. Meanwhile, during the 1997 Asian crisis, higher LERNER has no longer a destabilizing impact, even though bank capital ratios become lower. Specifically, higher market power in banking has a negative impact on risk taking (SDROA and SDROE) and a positive impact on bank solvency (ZROA and ZROE).

Insert Table 6 here

Such findings could be due to the fact that, during a financial crisis that has directly affected Asian banks, the degree of banks' risk aversion is higher. Hence banks might be shrinking their lending activities and their exposure to systematic risk might be lower. Also, during a financial crisis, banks could experience a massive decline in their capital ratios that in turn could exacerbate capital crunch problems (Bernanke and Lown, 1991). In this context, bank moral hazard in terms of imprudent lending decisions is presumably less likely to operate.

Moreover, the increasing role of foreign ownership, foreign banks or foreign direct investments in the Asian banking industry during the 1997 Asian crisis, as documented by Williams and Nguyen (2005), Moshirian (2008) or Jeon et al. (2011), could also explain a stabilizing impact of LERNER during a crisis period. In their theoretical model, Althammer 
and Haselmann (2011) show that during crisis periods in emerging markets, foreign banks from industrialized countries tend to enter emerging markets because of the loss of comparative advantage that domestic banks endure in unstable credit market conditions. In times of crisis, it is perceived that hard information on borrowers' profile is relatively more important than soft information. Hence, a better screening technology to value borrowers based on hard information enables foreign banks to increase their market share in emerging markets. In this regard, higher degree of market power in emerging markets' banking sectors during a financial crisis could be influenced by an increase in foreign banks' market share which in turn could have a stabilizing impact. Hence, in some sense, our findings also provide empirical support for Althammer and Haselmann (2011).

Further, we again repeat the estimations conducted in Section 5.1 for the 2007-2009 period to analyze whether the impact of market power in the banking industry on bank capital ratios, risk taking, and insolvency risk has changed during the 2008 global credit crisis. Table 7 presents our empirical results for the 2007-2009 period. During the 2008 crisis, LERNER is significantly and positively associated with bank capital ratios (EQTA or CAR). Higher LERNER is also positively related to bank risk-taking (SDROE) and insolvency risk (ZROE), but only at the $10 \%$ level. Hence, according to our results the 2008 crisis has not affected the risk-taking behavior of Asian banks in general as much as the 1997 crisis. As a whole, banks in less competitive markets still exhibit higher insolvency risks during the 2008 crisis period. This finding can be explained by the fact that the 2008 crisis did not directly affect Asian banks (Standard and Poor, 2008). As such, the risk-taking behavior of banks from 1994 to 2009 has not significantly changed during the 2008 crisis.

Insert Table 7 here 


\subsection{Additional analysis: The role of too-big-to-fail subsidies}

In this section, we focus on moral hazard issues that could operate in Asian banks. Cook (2009) points out that during the 1997 Asian crisis, some countries in Asia had suffered from bank moral hazard in the form of "gambling for resurrection" and "looting" 12 . Since our results in Section 5.2 show that market power in banking has a stabilizing impact in all Asian countries during the 1997 Asian crisis, we now extend the analysis by examining whether or not the competition-stability links are country-specific.

For this purpose, the country-specific factor we use to assess moral hazard issues is the extent to which the banking sector might benefit from too-big-to-fail subsidies, since it is well-known that bailout policies could exacerbate moral hazard in banking. Specifically, we consider another additional explanatory variable, TBTS, measured as the ratio of three largest banks' total assets to GDP and calculated from Beck and Demirgüç-Kunt (2009). Higher TBTS reflects that the banking system is "too big to save" and hence, central banks need to engage in higher bailout subsidies, at least for the largest banks. To better assess the role of market power in banking, moreover, we also incorporate the interaction term between market power in banking and the too-big-to-save effects $\left(L E R N E R^{*} T B T S\right)^{13}$. Table 8, Table 9 and Table 10 present our results for the overall period, the 1997-1999 period and the 2007-2009 period, respectively.

In Table 8, we report that higher LERNER leads to higher capital ratios, risk taking and insolvency risk of banks for the 1994-2009 period. In contrast, these results are reversed when we consider LERNER*TBTS, while the absolute values of the coefficients of $L E R N E R * T B T S$ are higher than those of LERNER. Hence moral hazard behavior that encourages banks to

\footnotetext{
12 Gambling for resurrection is a strategy of distressed banks to maintain profitability by excessively increasing loans to high-risk but high-return borrowers. Meanwhile, distressed banks also tend to increase deposit rates in order to attract more deposits to fund these loans. Looting is a strategy of distressed banks to extend loans at "below-market" rates to related corporations (La Porta et al, 2001).

${ }^{13}$ Since $L E R N E R$ is treated as endogenous variable, we also treat $L E R N E R * T B T S$ as endogenous variable. The similar approach is also used by Schaeck and Cihak (2010) in assessing the joint impact of bank competition and economic development on bank capital ratios.
} 
increase risk in less competitive markets only occur in countries with lower too-big-to-fail potential subsidies.

Insert Table 8 here

Our results are somehow consistent with Acharya et al (2012), although they analyze the joint role of the lender of last resort and market power in interbank markets in overcoming bank liquidity risk. In their model, banks in less competitive interbank markets are more likely to face higher cost of interbank lending. In this regard, the role of central banks to provide liquidity, particularly during crisis periods, is essential to improve the private allocation of liquidity among banks.

The role of the lender of last resort is indeed relatively more important during crisis periods than normal periods. In the Asian crisis period, Table 9 presents how the interaction term between market power and too-big-to-fail subsidies in banking (LERNER*TBTS) affects bank risk taking for the 1997-1999 period. Our findings show that the negative impact of market power in banking on bank income volatility and insolvency risk, despite lower capital ratios, only holds in countries with lower too-big-to-fail subsidies. This indicates that the stabilizing impact of higher market power in banking during the 1997 Asian crisis only holds for countries with lower too-big-to-fail subsidies. In this regard, bank consolidation policies aiming to enhance market power in the banking industry might not be effective in enhancing bank stability, unless the role of lender of last resort in providing too-big-to-fail subsidies is limited.

Insert Table 9 here 
Our results for the 1997-1999 period are consistent with Cook (2009) who states that during the Asian crisis, some Asian countries had suffered from severe bank moral hazard behavior. We provide further explanation for Cook (2009) that such countries are the ones with the highest too-big-to-fail potential subsidies. Therefore in the presence of higher toobig-to-fail subsidies because of the presence of significantly large banks, bank consolidations that aim to enhance market power in banking are likely to be ineffective to limit the risktaking behavior of banks during crisis periods.

Finally, Table 10 presents the joint impact of market power and too-big-to-fail subsidies in banking on the risk behavior of banks for the 2007-2009 period. The results over this period are similar to the ones for the 1994-2009 period. In countries with lower too-bigto-fail subsidies, higher market power in banking seems to have a destabilizing impact.

Insert Table 10 here

\section{Sensitivity analyses}

In order to ensure the robustness of our results, we perform several sensitivity analyses. For brevity, the results of these sensitivity analyzes are not reported in the paper but are available from the authors on request.

First, we re-estimate all the regressions presented in Section 5 by using the Generalized Methods of Moments (GMM) instead of the 2SLS method. Within this framework we also treat $L E R N E R$ and $L E R N E R * T B T S$ as endogenous variables instrumented by ECOFREE, RLAW and STOCK. Our overall findings remain the same.

Second, differences in macroeconomic and financial environments such as degree of development and financial structure, as well as institutional factors that affect economic and political characteristics, may explain bank risk exposures. To account for this dimension, we 
incorporate country-specific dummy variables as explanatory variables in (2) ${ }^{14}$. Indonesia is treated as the numeraire country. As country-specific dummies are time-invariant variables, individual fixed effects corrections are thus no longer applicable. By specifying the 2SLS estimation with time fixed-effect corrections, our main empirical findings discussed in Section 5 are not altered.

Third, the trends in financial globalization in Asia might change the nature of banking products from traditional activities (deposits funded loans) to non-interest income generating activities. Therefore, bank non-interest income may also explain some of the risk exposure of banks. We thus incorporate the ratio of non-interest income to total revenue $(N N I)$ as an explanatory variable in (2). Moreover, we also take into account the annual loan growth rate (LOANG) as one of the control variables that affect bank capitalization (Ayuso et al., 2004). Using this new specification, our main findings remain consistent, even though we lose a substantial number of observations.

Fourth, we modify the degree of market power in the banking industry by considering alternative specifications of the inverse demand function, as shown in (1). We use $O P L$ (the ratio of operating expenses to total loans) instead of $T A$ in the demand function, as bank monitoring costs can affect the pricing of bank loans. We also include the inflation rate (INF) to replace the short-term interest rate $(I R)$. This alternative specification does not alter our main findings obtained in Section 5.

\section{Summary and concluding remarks}

In spite of a strong consolidation in Asian banking, there is no evidence that such a process enhances bank stability. This paper attempts to assess such an issue by investigating the impact of market power in banking on bank capital ratios, risk taking, and insolvency risk.

\footnotetext{
${ }^{14}$ Agusman et al. (2008) also use the similar approach to account for unobservable country-specific characteristics in the Asian context.
} 
Based on a sample of 636 commercial banks in 11 Asian countries over the 1994-2009 period, our empirical results highlight that a higher degree of market power in banking is associated with an increase in bank risk taking and bank insolvency risk although capital ratios are also higher. However, these findings do not hold during the 1997 Asian crisis period (1997-1999), where higher market power decreases bank risk taking and insolvency risk. These results are robust to several sensitivity analyses.

Specifically, our findings show that in general, the increase in capital ratios in less competitive environments is not high enough to offset the effect of higher risk taking on bank insolvency risk, highlighting possible moral hazard problems in Asian banks. During a financial crisis, our results for the 1997-1999 period show that lower competition has a stabilizing effect which is opposite to what we find in the overall period of study and in the 2007-2009 period. Under such circumstances, higher market power in the banking industry might contribute to reduce moral hazard, at least in the crisis period that has directly affected Asian banking.

A closer investigation is also conducted to examine whether or not such results are country specific. Indeed some Asian countries suffered from relatively more severe bank moral hazard problems in the form of "gambling for resurrection" or "looting", particularly during the 1997 Asian crisis period. As such, the length of the crisis and the degree of economic recovery differed from one country to another. By incorporating the role of too-bigto-fail subsidies as a country-specific factors, our results are reversed for countries with larger banks which could force central banks to engage in higher amounts of too-big-to-fail subsidies.

These findings have various policy implications with regards to bank consolidation policies and the role of the lender of last resort. In the Asian context, market power in the banking industry, which is expected to enhance self-discipline induced by lower competition, 
does generally neither moderate bank risk taking nor provide enough incentives for banks to hold sufficiently more capital to prevent higher insolvency risk, except when the behavior of the lender of resort in providing too-big-to-fail subsidies is more stringent to limit bank moral hazard incentives. Specifically, our results indicate that during financial crises that directly affect Asian banks, the stabilizing effect of market power is only effective for countries with smaller large banks i.e. when the role of lender of resort is more limited. On the whole in achieving bank stability public authorities need to consider the degree of competitiveness of the banking system but also the size of the largest so-called systemic banks.

\section{References}

Acharya, V., Gromb, D., Yorulmazer, T., 2012. Imperfect competition in the interbank market for liquidity as a rational for central banking. Americal Economic Journal: Macroeconomic 4(3), 184-217.

Adams, C., 2008. Emerging East Asian banking system: Ten years after the 1997/98 crisis. ADB Working Paper Series on Regional Economic Integration No.16

Agoraki, M.K., Delis, M.D., Pasiouras, F., 2009. Regulations, competition and bank risk taking in transition countries. Journal of Financial Stability (doi:10.1016/j.jfs.2009.08.002)

Agusman, A., Monroe, G.S., Gasbarro, D., Zumwalt, J.K., 2008. Accounting and capital market measures of risk: Evidence from Asian banks during 1998-2003. Journal of Banking and Finance 32, 480-488

Agusman, A., Gasbarro, D., Zumwalt, J.K., 2006. Bank moral hazard and the disciplining factors of risk taking: evidence from Asian banks during 1998-2003. FMA European Conference proceedings, 1-44

Althammer, W., Haselmann, R., 2011. Explaining foreign bank entrance in emerging markets. Journal of Comparative Economics 39(4), 486-498.

Ariss, R.T., 2010. On the implications of market power in banking: Evidence from developing coutnries. Journal of Banking and Finance 34 (4), 765-775

Ayuso, J., Perez, D., Saurina, J. 2004. Are capital buffers pro-cyclical? Evidence from Spanish panel data. Journal of Financial Intermediation 13, 249-264

Beck, T., Dermirguc-Kunt, A., Levine, R., 2006. Bank concentration, competition and crises: First results. Journal of Banking and Finance 30, 1581-1603 
Beck T., 2008. Bank competition and financial stability: friends or foes? Working paper series, 4656, World Bank, Washington, DC

Beck, T., Demirgüç-Kunt, A., 2009. Financial institutions and markets across countries and over time: Data and analysis. Working paper series, 4943, World Bank, Washington, DC

Behr, P., Schmidt, R.H., Xie, R., 2010. Market structure, capital regulation, and bank risk taking. Journal of Financial Services Research 37(2-3), 131-158

Berger, A.N., Klapper, L.F., Ariss, R.T., 2009a. Bank competition and financial stability. Journal of Financial Services Research 35, 99-118

Berger, A.N., Bouwman, C.H.S., 2009b. Bank capital, survival, and performance around financial crises. Working Paper, MIT, Wharton Financial Institutions Center

Bernanke, B. S., Lown, C. S., 1991. Credit crunch, Brookings Papers on Economic Activity 2, 205-47.

Besanko, D., Thakor, A.V., 1993. Relationship banking, deposit insurance, and bank portfolio. In : C. Mayer and X.Vives (eds), Capital Market and Financial Intermediation, Cambridge, UK: Cambridge University Press, 262-265

Bikker, J.A., Bos, J.W.B., 2008. Bank Performance: A Theoretical and Empirical Framework for the Analysis of Profitability, Competition and Efficiency. Routledge International Studies in Money and Banking, New York

Blum, J.M., 2003. The impact of bank capital requirements on banks' incentives to monitor and to hold excess capital. National Bank of Switzerland Working Paper.

Bofondi, M., Gobbi, G., 2004. Bad loans and entry into local credit markets. Working paper series, 509, Bank of Italy

Borio, C., Furfine, C., Lowe, P. 2001. Procyclicality of the Financial System and the Financial Stability: Issues and Policy Options. Bank for International Settlements, Working Paper 1, 157

Boyd, J.H., De Nicolo, G., 2005. The theory of bank risk taking and competition revisited. Journal of Finance 60, 1329-1343

Boyd, J.H., De Nicolo, G., Jalal, A.M., 2006. Bank risk-taking and competition revisited: new theory and new evidence. Working paper series 06/297, International Monetary Fund, Washington, DC

Brissimis, S.N., Delis, M.D., Papanikolaou, N.I., 2008. Exploring the nexus between banking sector reform and performance: Evidence from newly acceded EU countries. Journal of Banking and Finance 32, 2674-2683

Broecker, T., 1990. Creditworthiness tests and interbank competition. Econometrica 58, 429452 
Brownbridge, M., Kirkpatrick, C. 1999. Financial sector regulation: The lessons of the Asian crisis. Development Policy Review 17, 243-266

Chang, R., Velasco, A., 2001. A model of financial crises in emerging markets. The Quarterly Journal of Economics 116 (2)

Cho, Y.J., 1986. Inefficiencies from Financial Liberalization in the Absence of WellFunctioning Equity Markets. Journal of Money. Credit and Banking 26 (2), 341-344

Claessens, S., Laeven, L., 2004. What drives bank competition? Some international evidence. Journal of Money, Credit and Banking 36, 563-583

Cook, M., 2009. Banking Sector Reform in South East Asia: The Region's Decisive Decade. Routledge Taylor and Francis Group, New York

Das, A., Nag, A., Ray, S.C., 2004. Liberalization, ownership, and efficiency in Indian banking: A Nonparametric Approach. Working Paper, University of Connecticut

Dash, M., Cristable, C., 2009. A study of technical efficiency of banks in India. Working Paper, Alliance Business Academy

De Guevara, J.F., Maudos, J., Perez, F., 2005. Market power in the European banking sector. Journal of Financial Services Research 27, 109-137.

Demsetz, R.S., Saidenberg, M.R., Strahan, P.E., 1996. Banks with something to lose: the disciplinary role of franchise value. Economic Policy Review, 1-14

DeYoung, R., Evanoff, D., Molyneux, P., 2009. Mergers and acquisitions of financial institutions: A review of the post-2000 literature. Journal of Financial Services Research 36, $87-110$

Domanski, D. 2005. Foreign banks in emerging economies: Changing players changing issues. BIS Quarterly Review, 69-81

Dornbush, R., Reynoso, A,. 1989. Financial Factors in Economic Development. American Economic Review79 (2), 204-209

Fry, M .J., 1988. Money. Interest and Banking in Economic Development. The John Hopkins University Press. Baltimore

Fungáčová, Z., Weill, L., 2009. How market powers influences bank failures: Evidence from Russia. Working Paper, Bank of Finland

Gefang, D., Koop, G., Potter, S.M., 2011. Understanding liquidity credit risks in the financial crisis. Working Paper, University of Strathclyde, UK.

Gonzales, F., 2005. Bank regulation and risk-taking incentives: an international comparison of bank risk. Journal of Banking and Finance 29(5), 1153-1184

Jensen, K., 1989. Monetary Policy and Financial Development. In Financing Economic Development : A structural Approach of Economic Development. Fitzgerald, E.V.K., Gower, 


\section{R.Vos. Publishing Company Ltd. Brookfield}

Jeon, B.N., Olivero, M.P., Wu, J., 2011. Do foreign banks increase competition? Evidence from emerging Asian and Latin American banking markets. Journal of Banking and Finance $35(4), 856-875$.

Jimenez, G., Lopez, J.A., Saurina, J., 2008. How does competition impact bank risk taking. Working Paper, Bank of Spain

Jokipii, T., Milne, A. 2008. The cyclical behaviour of European bank capital buffers. Journal of Banking \& Finance 32, 1440-1451

Kane, E.J., 2000. Incentives for bank megamergers: what motives might regulators infer from event-study evidence? Journal of Money, Credit and Banking 32, 671-701.

Kaufmann, D., Kraay, A., Mastruzzi, M., 2008. Governance Matters VII : Aggregate and Individual Governance Indicators 1996-2007. Working paper series, 4654, World Bank, Washington, DC

Keeley, M.C., 1990. Deposit insurance, risk and market power in banking. American Economic Review 80(5), 1183-1200

Klingebiel, D., Kroszner, R., Laeven, L., Oijen, P.V., 2001. Stock market responses to bank restructuring policies during the East Asian crisis. Working paper series, 2571, World Bank, Washington, DC

Laeven, L., 1999. Risk and efficiency in East Asian banks. Working paper series, 2255, World Bank, Washington, DC

La Porta, R., Lopez-de-Silanes, F. Zamarripa, G. 2001. Related lending. Quarterly Journal of Economics 118(1), 231-268

Lepetit, L., Nys, E., Rous, P., Tarazi, A., 2008.a. Bank income structure and risk : Empirical analysis of European banks. Journal of Banking and Finance 32, 1452-1467.

Lepetit, L., Nys, E., Rous, P., Tarazi, A., 2008.b. The expansion of services in European banking: Implications for loan pricing and interest margins. Journal of Banking and Finance $32,2325-2335$.

Levy-Yeyati, E., Micco, A. 2007. Concentration and foreign penetration in Latin American banking sectors: Impact on competition and risk. Journal of Banking and Finance 31, 1633 1647

Liu, H., Nguyen, L. and Molyneux, P. (2011) Competition and risk in South East Asian commercial banking. Applied Economics (forthcoming)

Marcus, A.J., 1984. Deregulation and bank financial policy. Journal of Banking and Finance $8,557-565$

Matutes, C., Vives, X., 1996. Competition for deposits, fragility and insurance. Journal of 
Financial Intermediation 5(2), 184-216

Moshirian, F., 2008. Financial services in an increasingly integrated global financial market. Journal of Banking and Finance 32 (11), 2288-2292

Moshirian, F., 2009. Can Asia Pacific Community similar to the European Community emerge? Journal of Banking and Finance 33, 2-8

Panzar, J.C., Rosse, J.N., 1987. Testing for 'monopoly' equilibrium. Journal of Industrial Economics 35 (4), 443-456.

Park, Y.C., 2006. Economic liberalisation and integration in East Asia: A post-crisis paradigm. Oxford University Press

Sachs, J., W.T. Woo, 2000. Understanding the Asian financial crisis. In : J. D. Sachs \& K. Schwab (Eds.), The Asian financial crisis: Lessons for a resilient Asia. MIT Press

Santoso, W. 2009. "Comment on "The Determinants of Cross-Border Merger and Acquisition Activity in the Banking Sector in Asia: Did the Asian Financial Crisis Change Them?" NBER Chapters, in: Financial Sector Development in the Pacific Rim, East Asia Seminar on Economics, Volume 18, 236-240 National Bureau of Economic Research, Inc

Shanmugam, K.R., Das, A., 2004. Efficiency of Indian commercial banks during the reform period. Applied Financial Economics 14, 681-686

Schaeck, K, Cihak, M., Wolfe, S., 2009. Are More Competitive Banking Systems More Stable? Journal of Money, Credit and Banking 41(4), 711-734

Schaeck, K., Cihak, M., 2010. Banking competition and capital ratios. European Financial Management, DOI: 10.1111/j.1468-036X.2010.00551.x

Sengupta, R., Tam, Y.M., 2008. The LIBOR-OIS spread as a summary indicator. Federal Reserve Bank of Saint Louis Economic Synopses 25.

Soedarmono, W., Machrouh, F., Tarazi, A., 2011. Bank market power, economic growth and financial stability: Evidence from Asian banks. Journal of Asian Economics 22(6), 460-470

Soedarmono, W., 2010. Bank competition, institution and economic development: Evidence from Asia during 1999-2007. Economics Bulletin 30(3), 2119-2133

Standard and Poor, 2008. Slower economic growth poses turbulence but no crisis for Asian banking system. RatingsDirect, September

Stiglitz, J., Weiss, A., 1981. Credit rationing with imperfect information. American Economic Review 71, 393-410

Taylor, L., 1983. Structuralist Macroeconomics : Applicable Models for the Third World. New-York. Basic Books

Uchida, H., Tsutsui, Y., 2005. Has competition in the Japanese banking sector improved? 
Journal of Banking and Finance 29, 419-439

Uhde, A., Heimeshoff, U., 2009. Consolidation in banking and financial stability in Europe: Empirical evidence. Journal of Banking and Finance 33, 1299-1311

Vives, X., 2001. Competition in the changing world of banking. Oxford Review of Economic Policy 17(4), 535-547

Williams, J., Nguyen, N., 2005. Financial liberalisation, crisis, and restructuring: A comparative study of bank performance and bank governance in South East Asia. Journal of Banking and Finance 29, 2119-2154 
Appendix A. Descriptive statistics, the degree of bank competition and the correlation structure

Table 1. Descriptive statistics

\begin{tabular}{|c|c|c|c|c|c|c|c|c|c|c|}
\hline \multirow[b]{2}{*}{ Variables } & \multirow[b]{2}{*}{ Definition } & \multicolumn{3}{|c|}{ Overall period } & \multicolumn{3}{|c|}{ 1997-1999 } & \multicolumn{3}{|c|}{$2007-2009$} \\
\hline & & Mean & Median & Std. Dev. & Mean & Median & Std. Dev. & Mean & Median & Std. Dev. \\
\hline$Q$ & Total earning assets (million USD) & 12222.52 & 1348.853 & 60736.07 & 5929.383 & 844.8070 & 25203.56 & 30771.10 & 3985.785 & 118645.9 \\
\hline$C$ & Total expenses (million USD) & 87535.96 & 297.1870 & 547422.7 & 103961.1 & 310.2390 & 622289.3 & 1260.945 & 231.3815 & 3882.355 \\
\hline$D$ & Total deposits and short term funding (million USD) & 10349.27 & 1133.506 & 56588.01 & 5271.261 & 684.3860 & 24055.55 & 25421.58 & 3230.881 & 111212.5 \\
\hline$R$ & Total revenue (million USD) & 72277.64 & 159.0305 & 498259.1 & 88956.24 & 156.2255 & 576800.6 & 1300.721 & 155.6240 & 4765.787 \\
\hline$W$ & Ratio of total operating expenses to total assets & 0.024736 & 0.019872 & 0.025543 & 0.028478 & 0.021725 & 0.039752 & 0.021465 & 0.016132 & 0.016517 \\
\hline$r$ & Ratio of interest expenses to total deposits & 10.17837 & 0.081984 & 21.32785 & 10.06263 & 0.096854 & 22.75490 & 0.167836 & 0.054747 & 2.648107 \\
\hline$P$ & Ratio of total revenue to total earning assets & 13.89216 & 0.108187 & 33.43061 & 20.92129 & 0.121982 & 49.65530 & 0.093718 & 0.074650 & 0.312308 \\
\hline$I R$ & Annual short-term interest rate & 0.079811 & 0.060000 & 0.076506 & 0.130744 & 0.076100 & 0.138827 & 0.057196 & 0.045150 & 0.050944 \\
\hline$C A R$ & Total risk-based capital ratio & 0.171273 & 0.135000 & 0.117333 & 0.174135 & 0.134800 & 0.125041 & 0.165533 & 0.138400 & 0.096281 \\
\hline$R O A$ & Ratio of net income to total assets & 0.006952 & 0.009185 & 0.042385 & -0.008159 & 0.006512 & 0.085721 & 0.009173 & 0.009563 & 0.012600 \\
\hline EQTA & Ratio of total equity to total asset & 0.115373 & 0.082281 & 0.116448 & 0.118956 & 0.083999 & 0.126046 & 0.109291 & 0.084159 & 0.083401 \\
\hline$S D R O A$ & Standard deviation of $R O A$ from a three-period rolling window & 0.011810 & 0.003223 & 0.038869 & 0.020430 & 0.004544 & 0.057511 & 0.004382 & 0.002542 & 0.006085 \\
\hline ZROA & Z-score based on $R O A$ from a three-period rolling window & 46.38470 & 27.54334 & 55.55249 & 35.51505 & 18.50050 & 49.61298 & 54.59037 & 34.61422 & 58.01816 \\
\hline$R O E$ & Ratio of net income to total equity & 0.105095 & 0.112044 & 0.110433 & 0.069151 & 0.085259 & 0.142713 & 0.111831 & 0.118142 & 0.091134 \\
\hline SDROE & Standard deviation of $R O E$ from a three-period rolling window & 0.051170 & 0.031049 & 0.062242 & 0.066636 & 0.041072 & 0.075671 & 0.038990 & 0.027433 & 0.040473 \\
\hline ZROE & Z-score based on $R O E$ from a three-period rolling window & 55.66345 & 34.75530 & 63.18721 & 48.06956 & 26.30093 & 63.01023 & 59.46329 & 39.10669 & 60.98926 \\
\hline$D E P O$ & Ratio of total deposits and short-term funding to total assets & 0.717629 & 0.777788 & 0.194707 & 0.738272 & 0.800764 & 0.191476 & 0.679291 & 0.738749 & 0.188114 \\
\hline$L L P$ & Ratio of loan loss provisions to total loans & 0.020282 & 0.008244 & 0.054388 & 0.046532 & 0.016244 & 0.099020 & 0.012249 & 0.007053 & 0.020285 \\
\hline$L O A N$ & Ratio of loans to total assets & 0.528797 & 0.540063 & 0.181783 & 0.526862 & 0.532720 & 0.194523 & 0.543911 & 0.565570 & 0.147986 \\
\hline SIZE & Logarithm of total assets & 7.329382 & 7.330009 & 2.018536 & 6.899275 & 6.848789 & 1.907663 & 8.439116 & 8.387506 & 1.917025 \\
\hline FOREXG & Annual growth rate of foreign exchange reserves & 0.209472 & 0.164791 & 0.298904 & 0.189931 & 0.171579 & 0.355178 & 0.186091 & 0.227672 & 0.242259 \\
\hline$G D P G$ & Annual growth rate of GDP & 0.054326 & 0.058490 & 0.034589 & 0.058407 & 0.059400 & 0.017867 & 0.072536 & 0.075570 & 0.025387 \\
\hline INF & Annual inflation rate & 0.059840 & 0.046370 & 0.060620 & 0.036183 & 0.031020 & 0.034491 & 0.091477 & 0.083790 & 0.077255 \\
\hline$R L A W$ & Rule of law index & 0.606502 & 0.558000 & 0.122908 & 0.619652 & 0.620000 & 0.120793 & 0.603925 & 0.544000 & 0.114069 \\
\hline ECOFREE & Economic Freedom index & 0.069219 & -0.001098 & 0.637029 & 0.083394 & 0.030354 & 0.569494 & 0.034358 & -0.133680 & 0.713358 \\
\hline STOCK & Ratio of stock market capitalization to GDP & 0.874326 & 0.364420 & 1.146663 & 0.650178 & 0.281605 & 0.790303 & 1.624380 & 1.184202 & 1.705325 \\
\hline TBTS & Ratio of three largest banks' total assets to GDP & 0.379762 & 0.253653 & 0.282787 & 0.361802 & 0.244049 & 0.236228 & 0.413357 & 0.255648 & 0.305100 \\
\hline
\end{tabular}


Table 2. The Lerner index in the Asian banking industry. The Lerner index is calculated from the new industrial organization approach following Uhida and Tsutsui (2005). A higher (lower) Lerner index is associated with an increase (decrease) in market power in banking.

\begin{tabular}{|c|c|c|c|c|c|c|c|c|c|c|c|}
\hline Year & China & $\begin{array}{c}\text { Hong- } \\
\text { Kong }\end{array}$ & Indonesia & India & South Korea & Sri Lanka & Malaysia & Philippines & Pakistan & Thailand & Vietnam \\
\hline 1994 & -0.282952 & 0.076967 & 0.346579 & -0.961778 & 0.13124 & 0.175771 & 0.993463 & 0.13994 & 0.071763 & 0.665669 & 0.27045 \\
\hline 1995 & -0.245039 & -0.061084 & 0.234224 & -0.865748 & 0.11629 & 0.116581 & 0.991431 & 0.133945 & 0.065709 & 0.60233 & 0.201964 \\
\hline 1996 & -0.245702 & -0.009032 & 0.204867 & -0.795948 & 0.099509 & 0.12634 & 0.963911 & 0.16828 & -0.067709 & 0.598937 & 0.158095 \\
\hline 1997 & -0.260196 & -0.053753 & 0.539131 & -0.764381 & 0.144564 & 0.06195 & 0.932716 & 0.075777 & -0.000681 & 0.548435 & 0.120352 \\
\hline 1998 & -0.032251 & -0.235858 & 1.929107 & -0.659159 & 0.018185 & 0.044018 & 0.90165 & -0.073066 & 0.029227 & 0.362615 & 0.160778 \\
\hline 1999 & -0.316486 & -0.674633 & -0.16463 & -0.986989 & -0.349258 & -0.506732 & 0.666228 & -0.589532 & -0.292432 & 0.279809 & -0.144492 \\
\hline 2000 & -0.31412 & -0.674264 & -0.161723 & -0.981867 & -0.349958 & -0.50754 & 0.66644 & -0.589708 & -0.294237 & 0.280852 & -0.144491 \\
\hline 2001 & -0.319157 & -0.673588 & -0.161321 & -0.982514 & -0.347797 & -0.507557 & 0.666529 & -0.589205 & -0.292336 & 0.280939 & -0.144732 \\
\hline 2002 & 0.238017 & -0.670538 & -0.161139 & -0.981794 & -0.346779 & -0.507313 & 0.666583 & -0.588759 & -0.294709 & 0.280985 & -0.144813 \\
\hline 2003 & 0.300196 & -0.66807 & -0.160795 & -0.981951 & -0.344848 & -0.506933 & 0.666762 & -0.588055 & -0.293095 & 0.281521 & -0.144163 \\
\hline 2004 & 0.360446 & -0.668376 & -0.160011 & -0.982079 & -0.344368 & -0.506881 & 0.666432 & -0.58868 & -0.291035 & 0.282955 & -0.14416 \\
\hline 2005 & 0.34348 & 0.343875 & 0.367294 & -0.359394 & 0.45999 & 0.116659 & 0.737229 & 0.192296 & 0.58054 & 1.000406 & 0.341684 \\
\hline 2006 & 0.305246 & 0.200099 & 0.385675 & -0.381871 & 0.410134 & 0.118395 & 0.723376 & 0.165057 & 0.496203 & 0.883843 & 0.285954 \\
\hline 2007 & 0.338882 & 0.258267 & 0.488008 & -0.362753 & 0.368536 & -0.018932 & 0.733192 & 0.250056 & 0.416676 & 0.916002 & 0.340667 \\
\hline 2008 & 0.310007 & 0.32556 & 0.511161 & -0.384193 & 0.245958 & -0.049368 & 0.885034 & 0.169463 & 0.326171 & 0.971731 & 0.217162 \\
\hline 2009 & 0.384511 & 0.538758 & 0.524386 & -0.31296 & 0.237408 & -0.060188 & 0.957936 & 0.252745 & 0.283754 & 1.101859 & 0.398163 \\
\hline
\end{tabular}

Note: The Indian banking industry exhibits a negative market power throughout the sample period, which might reveal a non-optimizing behavior of banks. Dash and Cristabel (2009) support our findings since Indian banks experienced a sharp increase in their cost-to-income ratio during the 2003-2008 period while profitability has declined. Shanmugam and Das (2004) report that financial reforms during the 1992-1999 period have not helped banks to raise their interest margins. Das et al. (2004) also find that Indian banks were not much differentiated in terms of input or output technical efficiency, as well as cost efficiency. Such a non-optimizing behavior of Indian banks might be due to the fact that the Indian banking industry is still dominated by the public sector. In the meantime, we observe that almost all the countries in our sample, except Malaysia and Thailand, exhibit a negative value for the market power index during the periods following the 1997/1998 Asian crisis, suggesting that banks lose their market power during a downturn period which in turn impedes them to maintain profitability. Among these countries, many have experienced three distinct periods based on market power estimates with first a positive value until the 1997/1998 crisis followed by a negative value until 2004 which became again positive afterwards (Indonesia, South Korea, Philippines, Vietnam and to a lesser extent Pakistan). 
Table 3. The correlation structure of dependent, explanatory and control variables. Dependent variables include CAR, EQTA, SDROA, SDROE, ZROA and ZROE. The explanatory variable of interest is $L E R N E R$. The rest of variables is control variable. Definition of variables follows Table 1.

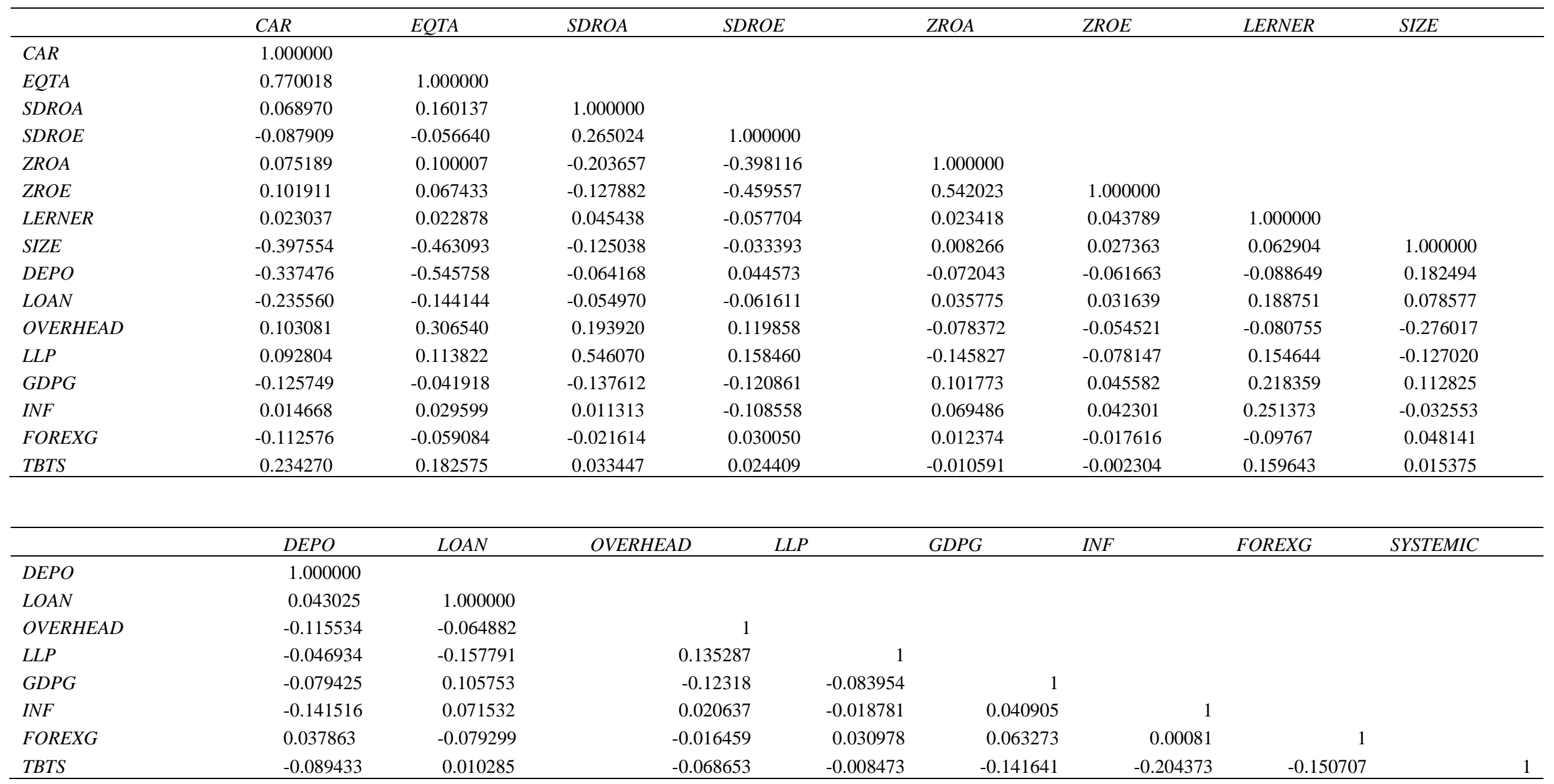




\section{Appendix B. Instrumental variables for LERNER}

The recent empirical literature sheds light on the endogeneity issue in the nexus between market power and bank risk taking (Berger et al., 2009; Uhde and Heimeshoff, 2009; Gonzales, 2005; Schaeck and Cihak, 2010). Indeed, bank competition can be affected by a number of bank-specific and macroeconomic factors that are not entirely captured in the competition measure. Reverse causality is also problem since bank risk and capital ratios can also affect bank competition. To deal with endogeneity that can arise from the competitionstability nexus, we specify instrumental variables for LERNER.

Claessens and Laeven (2004) argue that the quality of institutions that protects shareholders' rights is an important aspect for a well-functioning financial system. We thus consider $R L A W$ as one of the instrumental variables which may affect the degree of banking industry market power. Moshirian (2009) accentuates that the quality of the macro governance environment related to shareholders' protections will enhance the degree of financial globalization. If this is the case, higher $R L A W$ can reduce bank market power as the competition level of the financial system due to financial globalization increases.

Meanwhile, as discussed by Schaeck and Cihak (2010), a well developed financial market can change the competitive environment in which banks operate. By choosing STOCK as an instrumental variable, we aim to capture the effect of financial market development ${ }^{15}$. For instance, if the stock market is well developed, an increase in STOCK might imply that banks can choose to invest their funds on the stock market instead of providing loans to the private sector. Also, firms can have easier access to the market imposing more competitive pricing for bank loans. Finally, we also consider Economic Freedom (ECOFREE) as one of the instrumental variables for LERNER instead of the Banking Freedom indicator used by Berger et al. (2009), since the Economic Freedom index consists of a broader set of economic

\footnotetext{
${ }^{15}$ We have also used the ratio of private and public bond market capitalization to GDP (BOND). We prefer using STOCK because this variable is better disclosed than BOND for some countries. However, we also check the robustness by specifying BOND as the instrumental variable instead of STOCK. The main results are unaltered.
} 
openness indicators than the Banking Freedom index. ECOFREE is a composite index of 10 indicators ranking policies in the areas of trade, government finances, government interventions, monetary policy, capital flows and foreign investment, banking and finance, wages and prices, property rights, regulation and black market activity. The index scores from 0 to 100 with higher scores indicating policies being more conducive to competition and economic freedom. 


\section{Appendix C. Empirical results}

Table 4. Instrumental variables for bank competition measure. This table presents the first-stage regression between instrumental variables and market power in the banking industry. The dependent variable is the Lerner index (LERNER). LERNER is the market power index calculated from the new industrial organization approach following Uchida and Tsutsui (2005). ECOFREE is the economic freedom index retrieved from Heritage foundation. RLAW is the rule of law index constructed by Kaufmann et al. (2008). STOCK is the ratio of stock market capitalization to gross domestic product $(G D P) . D E P O$ is the ratio of total deposits to total assets. $L O A N$ is the ratio of total loans to total assets. $L L P$ is the ratio of loan loss provisions to total loans. OVERHEAD is the ratio of operating expenses to total assets. SIZE is the logarithm of total assets. FOREXG is the growth of foreign exchange reserves. GDPG is the growth rate of real GDP. $I N F$ is the inflation rate. A constant is included but not reported. The model is estimated using the Ordinary Least Squares method without fixed effects. The $t$-statistic values are reported in parentheses. $(* * *),(* *)$ and $(*)$ indicate significance at the $1 \%, 5 \%$ and $10 \%$ level, respectively. Muticollinearity problems exist if the VIF test exceeds 10 basis points.

\begin{tabular}{|c|c|c|c|}
\hline Explanatory variables & Overall period & 1997-1999 & $2007-2009$ \\
\hline ECOFREE & $\begin{array}{l}0.01466 * * * \\
(11.668)\end{array}$ & $\begin{array}{l}0.00818 * * \\
(2.4377)\end{array}$ & $\begin{array}{l}0.05166 * * * \\
(18.589)\end{array}$ \\
\hline$R L A W$ & $\begin{array}{l}-0.27981 * * * \\
(-13.655)\end{array}$ & $\begin{array}{l}-0.01178^{*} \\
(-0.14593)\end{array}$ & $\begin{array}{l}-0.45926 * * * \\
(-9.7015)\end{array}$ \\
\hline STOCK & $\begin{array}{l}0.07397 * * * \\
(7.6635)\end{array}$ & $\begin{array}{l}0.03291 * * \\
(0.67054)\end{array}$ & $\begin{array}{l}-0.14422 * * * \\
(-12.584)\end{array}$ \\
\hline$D E P O$ & $\begin{array}{l}-0.12652 * * * \\
(-2.8349)\end{array}$ & $\begin{array}{l}0.13216 \\
(0.98457)\end{array}$ & $\begin{array}{l}-0.09178^{*} \\
(-1.7115)\end{array}$ \\
\hline$L O A N$ & $\begin{array}{l}0.69381 * * * \\
(13.755)\end{array}$ & $\begin{array}{l}0.97431 * * * \\
(7.9992)\end{array}$ & $\begin{array}{l}0.31397 * * * \\
(3.9212)\end{array}$ \\
\hline$L L P$ & $\begin{array}{l}2.1571 * * * \\
(7.3714)\end{array}$ & $\begin{array}{l}2.9435 * * * \\
(7.2099)\end{array}$ & $\begin{array}{l}-0.4023 \\
(-0.87172)\end{array}$ \\
\hline OVERHEAD & $\begin{array}{l}-3.545 * * * \\
(-5.611)\end{array}$ & $\begin{array}{l}-6.5794 * * * \\
(-4.1668)\end{array}$ & $\begin{array}{l}-3.1365 * * * \\
(-3.7796)\end{array}$ \\
\hline SIZE & $\begin{array}{l}0.02041^{* * *} \\
(5.2358)\end{array}$ & $\begin{array}{l}-0.00237 \\
(-0.20193)\end{array}$ & $\begin{array}{l}0.01209 * * \\
(2.3051)\end{array}$ \\
\hline FOREXG & $\begin{array}{l}-0.17133 * * * \\
(-8.1079)\end{array}$ & $\begin{array}{l}-0.09112 * * \\
(-2.3262)\end{array}$ & $\begin{array}{l}-0.01114 \\
(-0.31504)\end{array}$ \\
\hline$G D P G$ & $\begin{array}{l}3.6965 * * * \\
(13.844)\end{array}$ & $\begin{array}{l}-2.6892 * * \\
(-2.1451)\end{array}$ & $\begin{array}{l}1.2798 * * * \\
(2.9841)\end{array}$ \\
\hline$I N F$ & $\begin{array}{l}1.6274 * * * \\
(12.695)\end{array}$ & $\begin{array}{l}8.2729 * * * \\
(7.9448)\end{array}$ & $\begin{array}{l}0.81574 * * * \\
(10.234)\end{array}$ \\
\hline R-square & 0.28 & 0.43 & 0.39 \\
\hline F-statistic & $149.74 * * *$ & $58.444 * * *$ & $51.46 * * *$ \\
\hline VIF test & 1.38 & 1.78 & 1.66 \\
\hline Number of observation & 4267 & 835 & 870 \\
\hline
\end{tabular}


Table 5. General results for the whole period. This table examines the impact of bank competition on capital ratio, risk taking and insolvency risk in banking for overall period. $L E R N E R$ is the market power index. LERNER_SQ is the squared term of LERNER. EQTA is the ratio of total equity to total assets. CAR is the total risk-based capital ratio. SDROA (SDROE) is the standard deviation of return on assets (equity) calculated from a three-period based rolling window. ZROA (ZROE) is the Z-score index based on $R O A$ (ROE). $D E P O$ is the ratio of total deposits to total assets. $L O A N$ is the ratio of total loans to total assets. $L L P$ is the ratio of loan loss provisions to total loans. OVERHEAD is the ratio of operating expenses to total assets. SIZE is the logarithm of total assets. FOREXG is the growth of foreign exchange reserves. GDPG is the growth rate of real gross domestic product (GDP). $I N F$ is the inflation rate A constant is included but not reported. The model is estimated using the 2SLS method with cross-section and time fixed-effect corrections. Instrumental variables for LERNER consist of ECOFREE (economic freedom), $R L A W$ (rule of law) and STOCK (the ratio of stock market capitalization to GDP). The $t$-statistic values are in parentheses. $(* * *)$ indicates significance at the $1 \%$ level, while $(* *)$ and $(*)$ indicate significance at the 5\% and $10 \%$ levels, respectively. Muticollinearity problems exist if the VIF test exceeds 10 basis points.

\begin{tabular}{|c|c|c|c|c|c|c|c|c|c|c|c|c|}
\hline \multirow[b]{2}{*}{ Explanatory variables } & \multicolumn{2}{|c|}{ CAR } & \multicolumn{2}{|c|}{$E Q T A$} & \multicolumn{2}{|c|}{ SDROA } & \multicolumn{2}{|c|}{ SDROE } & \multicolumn{2}{|c|}{ ZROA } & \multicolumn{2}{|c|}{ ZROE } \\
\hline & Model 1 & Model 2 & Model 1 & Model 2 & Model 1 & Model 2 & Model 1 & Model 2 & Model 1 & Model 2 & Model 1 & Model 2 \\
\hline \multirow[t]{2}{*}{ LERNER } & 0.26108 & $0.06519 * *$ & 0.03728 & $0.06022 * * *$ & $0.00377^{*}$ & $0.02314 * * *$ & 0.03351 & $0.04061 * * *$ & $-112.977 * * *$ & $-49.4404 * * *$ & $-125.489 * *$ & $-28.979 *$ \\
\hline & (3.0489) & $(2.1454)$ & $(0.80921)$ & $(4.0453)$ & $(0.18079)$ & $(3.3461)$ & $(0.61154)$ & (2.1499) & $(-2.1615)$ & $(-2.9229)$ & $(-2.0813)$ & $(-1.4239)$ \\
\hline \multirow[t]{2}{*}{ LERNER_SQ } & 0.28721 & & 0.01336 & & 0.01233 & & 0.05031 & & 41.139 & & $66.9287 *$ & \\
\hline & $(4.3725)$ & & $(0.52574)$ & & $(0.98311)$ & & (1.4448) & & $(1.2885)$ & & $(1.7064)$ & \\
\hline \multirow[t]{2}{*}{ DEPO } & $-0.15001 * * *$ & $-0.12338 * * *$ & $-0.13699 * * *$ & $-0.13479 * * *$ & -0.00144 & 0.00042 & $0.03082 * * *$ & $0.03807 * * *$ & $-44.269 * * *$ & $-38.067 * * *$ & $-38.597 * * *$ & $-29.236 * * *$ \\
\hline & $(-7.6591)$ & $(-9.1627)$ & $(-16.2312)$ & $(-18.2755)$ & $(-0.34585)$ & $(0.11431)$ & (2.7494) & $(3.8731)$ & $(-4.1428)$ & $(-4.0887)$ & $(-3.1392)$ & $(-2.7287)$ \\
\hline \multirow[t]{2}{*}{$L O A N$} & $-0.08687 * * *$ & $-0.16127 * * *$ & -0.00023 & -0.00492 & $-0.02144 * * *$ & $-0.02492 * * *$ & -0.02168 & $-0.03642 * * *$ & $41.069 * * *$ & $29.3521 * * *$ & $53.0501 * * *$ & $33.634 * * *$ \\
\hline & $(-3.2028)$ & $(-10.5531)$ & $(-0.01956)$ & $(-0.63902)$ & $(-4.0444)$ & $(-6.3419)$ & $(-1.4527)$ & $(-3.4079)$ & (3.0246) & $(2.9828)$ & $(3.2051)$ & $(2.8733)$ \\
\hline \multirow[t]{2}{*}{$L L P$} & $-0.31453 * * *$ & -0.08076 & $-0.19549 * * *$ & $-0.18929 * * *$ & $0.12179 * * *$ & $0.13053 * * *$ & -0.04055 & 0.02703 & -10.512 & 20.4892 & -32.1458 & 64.157 \\
\hline & $(-3.6176)$ & $(-1.6283)$ & $(-6.3749)$ & $(-6.6471)$ & $(7.4682)$ & (9.6005) & $(-0.5909)$ & $(0.54911)$ & $(-0.2512)$ & $(0.61318)$ & $(-0.40612)$ & (1.1871) \\
\hline \multirow[t]{2}{*}{ OVERHEAD } & $0.63031 * * *$ & $0.63739 * * *$ & $0.80308 * * *$ & $0.79943 * * *$ & $0.14201 * * *$ & $0.13946 * * *$ & $0.44489 * * *$ & $0.44237 * * *$ & $-268.918 * *$ & $-278.792 * *$ & $-322.645^{* *}$ & $-328.944 * *$ \\
\hline & (2.5992) & (3.6336) & $(9.9039)$ & $(9.8361)$ & (3.1012) & (3.0671) & (3.4143) & $(3.4641)$ & $(-2.3087)$ & $(-2.4581)$ & $(-2.2626)$ & $(-2.3698)$ \\
\hline \multirow[t]{2}{*}{ SIZE } & $-0.01991 * * *$ & $-0.03159 * * *$ & $-0.03561 * * *$ & $-0.03648 * * *$ & 0.00068 & -0.00021 & 0.00495 & 0.00152 & $6.7247 * *$ & 3.7786 & 1.0263 & -3.4845 \\
\hline & $(-3.3891)$ & $(-8.3502)$ & $(-14.2211)$ & $(-19.2181)$ & $(0.51577)$ & $(-0.21356)$ & (1.3939) & $(0.58639)$ & (1.9886) & $(1.5541)$ & $(0.26229)$ & $(-1.2403)$ \\
\hline \multirow{2}{*}{ FOREXG } & -0.01243 & $-0.01604 * *$ & $-0.00998 * * *$ & $-0.01031 * * *$ & $-0.00263 *$ & $-0.00262 *$ & -0.00108 & -0.00113 & $12.741 * * *$ & $12.981 * * *$ & 6.3467 & 6.3268 \\
\hline & $(-1.2125)$ & $(-2.1715)$ & $(-3.2873)$ & $(-3.4383)$ & $(-1.8088)$ & $(-1.8055)$ & $(-0.2795)$ & $(-0.29758)$ & $(3.4497)$ & $(3.6061)$ & $(1.4963)$ & (1.5319) \\
\hline \multirow[t]{2}{*}{$G D P G$} & $0.18987^{*}$ & -0.08576 & -0.01864 & -0.03672 & $-0.04001 * *$ & $-0.04853 * * *$ & -0.06214 & $-0.09495^{* *}$ & $88.268^{*}$ & 60.771 & $112.665^{*}$ & 68.539 \\
\hline & (1.6975) & $(-1.2831)$ & $(-0.36707)$ & $(-0.97753)$ & $(-2.0137)$ & $(-2.7315)$ & $(-1.1886)$ & $(-2.0574)$ & (1.7478) & $(1.3605)$ & (1.9483) & (1.3609) \\
\hline \multirow[t]{2}{*}{$I N F$} & $-0.10482 * *$ & 0.02738 & 0.03105 & $0.03824 * *$ & 0.00867 & $0.01526^{*}$ & -0.011627 & 0.01339 & -37.821 & -16.319 & -33.838 & -2.8813 \\
\hline & $(-2.1499)$ & $(0.99004)$ & $(1.4517)$ & $(2.3112)$ & $(0.82604)$ & $(1.9015)$ & $(-0.4179)$ & $(0.62756)$ & $(-1.4089)$ & $(-0.79523)$ & $(-1.1306)$ & $(-0.12431)$ \\
\hline R-square & 0.38 & 0.67 & 0.75 & 0.74 & 0.31 & 0.32 & 0.24 & 0.27 & 0.14 & 0.18 & 0.09 & 0.14 \\
\hline F-statistic & $14.494 * * *$ & $14.208 * * *$ & $24.405 * * *$ & $24.449 * * *$ & $4.81 * * *$ & $4.817 * * *$ & $3.709 * * *$ & $3.711 * * *$ & $2.686^{* * * *}$ & $2.686^{* * * *}$ & $2.114 * * *$ & $2.111 * * *$ \\
\hline VIF test & 1.97 & 3.76 & 4.71 & 4.66 & 1.72 & 1.74 & 1.57 & 1.64 & 1.38 & 1.45 & 1.32 & 1.39 \\
\hline Number of observation & 2826 & 2826 & 4220 & 4220 & 3944 & 3994 & 3852 & 3852 & 3901 & 3901 & 3774 & 3774 \\
\hline
\end{tabular}


Table 6. General results during the Asian crisis. This table examines the impact of bank competition on capital ratio, risk taking and insolvency risk in banking over the 1997-1999 period. LERNER is the market power index. LERNER_SQ is the squared term of $L E R N E R$. EQTA is the ratio of total equity to total assets. CAR is the total risk-based capital ratio. SDROA (SDROE) is the standard deviation of return on assets (equity) calculated from a three-period based rolling window. ZROA (ZROE) is the Z-score index based on ROA (ROE). DEPO is the ratio of total deposits to total assets. $L O A N$ is the ratio of total loans to total assets. $L L P$ is the ratio of loan loss provisions to total loans. OVERHEAD is the ratio of operating expenses to total assets. SIZE is the logarithm of total assets. FOREXG is the growth of foreign exchange reserves. GDPG is the growth rate of real gross domestic product (GDP). INF is the inflation rate. A constant is included but not reported. The model is estimated using the 2SLS method with cross-section and time fixed-effect corrections. Instrumental variables for LERNER consist of ECOFREE (economic freedom), RLAW (rule of law) and STOCK (the ratio of stock market capitalization to GDP). The $t$-statistic values are in parentheses. (***) indicates significance at the $1 \%$ level, while (**) and (*) indicate significance at the 5\% and $10 \%$ levels, respectively. Muticollinearity problems exist if the VIF test exceeds 10 basis points.

\begin{tabular}{|c|c|c|c|c|c|c|c|c|c|c|c|c|}
\hline \multirow[b]{2}{*}{ Explanatory variables } & \multicolumn{2}{|c|}{$C A R$} & \multicolumn{2}{|c|}{$E Q T A$} & \multicolumn{2}{|c|}{ SDROA } & \multicolumn{2}{|c|}{ SDROE } & \multicolumn{2}{|c|}{ ZROA } & \multicolumn{2}{|c|}{ ZROE } \\
\hline & Model 1 & Model 2 & Model 1 & Model 2 & Model 1 & Model 2 & Model 1 & Model 2 & Model 1 & Model 2 & Model 1 & Model 2 \\
\hline LERNER & $\begin{array}{l}-0.03612 \\
(-0.54607)\end{array}$ & $\begin{array}{l}-0.0872 * * * \\
(-3.9427)\end{array}$ & $\begin{array}{l}-0.08792 * * * \\
(-2.8289)\end{array}$ & $\begin{array}{l}-0.04317 \text { *** } \\
(-4.8516)\end{array}$ & $\begin{array}{l}0.04191 \\
(2.5531)\end{array}$ & $\begin{array}{l}0.01746 \\
(1.7399)\end{array}$ & $\begin{array}{l}-0.01502 \\
(-0.29193)\end{array}$ & $\begin{array}{l}-0.03363^{* *} \\
(-2.2115)\end{array}$ & $\begin{array}{l}75.063 * * * \\
(3.3049)\end{array}$ & $\begin{array}{l}26.991 * * \\
(2.2036)\end{array}$ & $\begin{array}{l}25.322 * \\
(1.5862)\end{array}$ & $\begin{array}{l}42.812 * * * \\
(4.7852)\end{array}$ \\
\hline LERNER_SQ & $\begin{array}{l}-0.02459 \\
(-0.81903)\end{array}$ & & $\begin{array}{l}0.02155 \\
(1.5054)\end{array}$ & & $\begin{array}{l}-0.01144 \\
(-1.6109)\end{array}$ & & $\begin{array}{l}-0.00918 \\
(-0.37896)\end{array}$ & & $\begin{array}{l}-22.386 * * \\
(-4.0733)\end{array}$ & & $\begin{array}{l}8.5259 * * \\
(2.0324)\end{array}$ & \\
\hline$D E P O$ & $\begin{array}{l}-0.04228 \\
(-0.60703)\end{array}$ & $\begin{array}{l}-0.06817 \\
(-1.0938)\end{array}$ & $\begin{array}{l}-0.21102 * * * \\
(-7.6809)\end{array}$ & $\begin{array}{l}-0.19562 * * * \\
(-7.8139)\end{array}$ & $\begin{array}{l}-0.02304 \\
(-0.79088)\end{array}$ & $\begin{array}{l}-0.02968 \\
(-1.0638)\end{array}$ & $\begin{array}{l}-0.02931 \\
(-0.62561)\end{array}$ & $\begin{array}{l}-0.03406 \\
(-0.75725)\end{array}$ & $\begin{array}{l}-12.428 \\
(-0.48301)\end{array}$ & $\begin{array}{l}-25.617 \\
(-1.1032)\end{array}$ & $\begin{array}{l}-66.877 \\
(-1.4772)\end{array}$ & $\begin{array}{l}-62.369 \\
(-1.3251)\end{array}$ \\
\hline$L O A N$ & $\begin{array}{l}-0.16777 * * * \\
(-3.4566)\end{array}$ & $\begin{array}{l}-0.15609 * * * \\
(-3.3502)\end{array}$ & $\begin{array}{l}0.06028 * * * \\
(3.2175)\end{array}$ & $\begin{array}{l}0.04759 * * * \\
(2.8969)\end{array}$ & $\begin{array}{l}-0.10414 * * * \\
(-2.7838)\end{array}$ & $\begin{array}{l}-0.09827 * * * \\
(-2.6941)\end{array}$ & $\begin{array}{l}-0.09151^{* * *} \\
(-2.8101)\end{array}$ & $\begin{array}{l}-0.08651^{* * * *} \\
(-2.9153)\end{array}$ & $\begin{array}{l}7.7527 \\
(0.52535)\end{array}$ & $\begin{array}{l}19.458 \\
(1.1866)\end{array}$ & $\begin{array}{l}90.642^{* * * *} \\
(6.2249)\end{array}$ & $\begin{array}{l}85.911^{* * * *} \\
(6.5755)\end{array}$ \\
\hline$L L P$ & $\begin{array}{l}0.28089 * * \\
(2.5241)\end{array}$ & $\begin{array}{l}0.28817^{* * *} \\
(2.5868)\end{array}$ & $\begin{array}{l}0.06464 * * \\
(2.0983)\end{array}$ & $\begin{array}{l}0.06373^{* *} \\
(2.1076)\end{array}$ & $\begin{array}{l}0.10306 * * \\
(2.1798)\end{array}$ & $\begin{array}{l}0.10396 \text { ** } \\
(2.1986)\end{array}$ & $\begin{array}{l}0.01345 \\
(0.23906)\end{array}$ & $\begin{array}{l}0.00907 \\
(0.16521)\end{array}$ & $\begin{array}{l}-37.299 \\
(-1.4193)\end{array}$ & $\begin{array}{l}-35.356 \\
(-1.6026)\end{array}$ & $\begin{array}{l}-25.197 \\
(-0.45802)\end{array}$ & $\begin{array}{l}-21.647 \\
(-0.39737)\end{array}$ \\
\hline OVERHEAD & $\begin{array}{l}0.40713 \\
(0.54231)\end{array}$ & $\begin{array}{l}0.31953 \\
(0.42819)\end{array}$ & $\begin{array}{l}0.05805 \\
(0.23641)\end{array}$ & $\begin{array}{l}0.07011 \\
(0.29089)\end{array}$ & $\begin{array}{l}0.18754 \\
(0.75206)\end{array}$ & $\begin{array}{l}0.17326 \\
(0.69644)\end{array}$ & $\begin{array}{l}-0.19957 \\
(-0.51872)\end{array}$ & $\begin{array}{l}-0.20363 \\
(-0.53117)\end{array}$ & $\begin{array}{l}-77.945 \\
(-0.55467)\end{array}$ & $\begin{array}{l}-104.57 \\
(-0.66832)\end{array}$ & $\begin{array}{l}599.075 * * * \\
(4.8711)\end{array}$ & $\begin{array}{l}604.368^{* * *} \\
(5.1612)\end{array}$ \\
\hline SIZE & $\begin{array}{l}-0.08222 * * * \\
(-3.7591)\end{array}$ & $\begin{array}{l}-0.07421 * * * \\
(-3.7768)\end{array}$ & $\begin{array}{l}-0.04325 * * * \\
(-4.9743)\end{array}$ & $\begin{array}{l}-0.05007 \text { *** } \\
(-6.8767)\end{array}$ & $\begin{array}{l}-0.02256 * * * \\
(-2.8251)\end{array}$ & $\begin{array}{l}-0.01883^{* *} \\
(-2.2784)\end{array}$ & $\begin{array}{l}-0.06269 * * * \\
(-3.9559)\end{array}$ & $\begin{array}{l}-0.05949 * * * \\
(-4.4479)\end{array}$ & $\begin{array}{l}2.9071 \\
(0.26816)\end{array}$ & $\begin{array}{l}10.214 \\
1.2235\end{array}$ & $\begin{array}{l}41.165^{* * *} \\
(3.4246)\end{array}$ & $\begin{array}{l}38.194 * * * \\
(3.1684)\end{array}$ \\
\hline FOREXG & $\begin{array}{l}0.00999 \\
(0.88514)\end{array}$ & $\begin{array}{l}0.01336 \\
(1.2641)\end{array}$ & $\begin{array}{l}0.00722 * \\
(1.8868)\end{array}$ & $\begin{array}{l}0.00634 * \\
(1.7079)\end{array}$ & $\begin{array}{l}-0.00549 * * \\
(-2.0887)\end{array}$ & $\begin{array}{l}-0.00503 * \\
(-1.9601)\end{array}$ & $\begin{array}{l}0.02127^{* * * *} \\
(3.4611)\end{array}$ & $\begin{array}{l}0.02159 * * * \\
(3.5596)\end{array}$ & $\begin{array}{l}2.9392 \\
(1.2434)\end{array}$ & $\begin{array}{l}3.8541^{*} \\
(1.9221)\end{array}$ & $\begin{array}{l}-3.5932 * * * \\
(-3.5472)\end{array}$ & $\begin{array}{l}-3.8734 * * * \\
(-2.9309)\end{array}$ \\
\hline$G D P G$ & $\begin{array}{l}0.53519 * \\
(1.7733)\end{array}$ & $\begin{array}{l}0.62862 * * \\
(2.2403)\end{array}$ & $\begin{array}{l}0.33723 * * \\
(2.2061)\end{array}$ & $\begin{array}{l}0.21291 * \\
(1.6857)\end{array}$ & $\begin{array}{l}-0.46761 * * * \\
(-3.9491)\end{array}$ & $\begin{array}{l}-0.39286 \text { *** } \\
(-3.6201)\end{array}$ & $\begin{array}{l}0.03989 \\
(0.14843)\end{array}$ & $\begin{array}{l}0.09815 \\
(0.44661)\end{array}$ & $\begin{array}{l}-567.002 * * * \\
(-4.6389)\end{array}$ & $\begin{array}{l}-417.979^{*} \\
(-1.8958)\end{array}$ & $\begin{array}{l}-259.567 * * * \\
(-1.7365)\end{array}$ & $\begin{array}{l}-316.956 * * * \\
(-3.2719)\end{array}$ \\
\hline$I N F$ & $\begin{array}{l}-2.0498 * * * \\
(-3.6286)\end{array}$ & $\begin{array}{l}-2.2975 * * * \\
(-4.7959)\end{array}$ & $\begin{array}{l}-0.88642 * * * \\
(-4.0291)\end{array}$ & $\begin{array}{l}-0.67546 \text { **** } \\
(-4.0564)\end{array}$ & $\begin{array}{l}0.69188 * * * \\
(3.4924)\end{array}$ & $\begin{array}{l}0.57758^{* * * *} \\
(2.9446)\end{array}$ & $\begin{array}{l}-0.10748 \\
(-0.30779)\end{array}$ & $\begin{array}{l}-0.18638 \\
(-0.66693)\end{array}$ & $\begin{array}{l}259.762 \\
(0.94869)\end{array}$ & $\begin{array}{l}38.809 \\
(0.18669)\end{array}$ & $\begin{array}{l}474.741 \\
(1.4935)\end{array}$ & $\begin{array}{l}549.659 * \\
(1.8835)\end{array}$ \\
\hline R-square & 0.78 & 0.78 & 0.87 & 0.87 & 0.51 & 0.51 & 0.61 & 0.61 & 0.37 & 0.34 & 0.49 & 0.49 \\
\hline F-statistic & $8.6654 * * *$ & $8.7084 * * *$ & $18.126^{* * *}$ & $18.103^{* * *}$ & $3.674 * * *$ & $3.683 * * *$ & $4.349^{* * *}$ & $4.371^{* * *}$ & $2.224 * * *$ & $2.224 * * *$ & $2.893 * * *$ & $2.907 * * *$ \\
\hline VIF test & 7.92 & 6.90 & 4.18 & 3.35 & 3.74 & 3.77 & 4.89 & 4.91 & 2.96 & 2.85 & 3.65 & 3.69 \\
\hline Number of Observation & 492 & 492 & 813 & 813 & 807 & 807 & 761 & 761 & 797 & 797 & 747 & 747 \\
\hline
\end{tabular}


Table 7. General results during the global credit crisis. This table examines the impact of bank competition on capital ratio, risk taking and insolvency risk in banking over the 2007-2009 period. LERNER is the market power index. LERNER_SQ is the squared term of LERNER. EQTA is the ratio of total equity to total assets. CAR is the total risk-based capital ratio. SDROA $(S D R O E)$ is the standard deviation of return on assets (equity) calculated from a three-period based rolling window. ZROA (ZROE) is the Z-score index based on $R O A$ (ROE). DEPO is the ratio of total deposits to total assets. $L O A N$ is the ratio of total loans to total assets. $L L P$ is the ratio of loan loss provisions to total loans. OVERHEAD is the ratio of operating expenses to total assets. $S I Z E$ is the logarithm of total assets. FOREXG is the growth of foreign exchange reserves. GDPG is the growth rate of real gross domestic product (GDP). INF is the inflation rate. A constant is included but not reported. The model is estimated using the 2 SLS method with cross-section and time fixed-effect corrections. Instrumental variables for $L E R N E R$ consist of ECOFREE (economic freedom), RLAW (rule of law) and STOCK (the ratio of stock market capitalization to GDP). The $t$-statistic values are in parentheses. (***) indicates significance at the $1 \%$ level, while $(* *)$ and $(*)$ indicate significance at the $5 \%$ and $10 \%$ levels, respectively. Muticollinearity problems exist if the VIF test exceeds 10 basis points.

\begin{tabular}{|c|c|c|c|c|c|c|c|c|c|c|c|c|}
\hline \multirow[b]{2}{*}{ Explanatory variables } & \multicolumn{2}{|c|}{$C A R$} & \multicolumn{2}{|c|}{$E Q T A$} & \multicolumn{2}{|c|}{ SDROA } & \multicolumn{2}{|c|}{ SDROE } & \multicolumn{2}{|c|}{ ZROA } & \multicolumn{2}{|c|}{ ZROE } \\
\hline & Model 1 & Model 2 & Model 1 & Model 2 & Model 1 & Model 2 & Model 1 & Model 2 & Model 1 & Model 2 & Model 1 & Model 2 \\
\hline LERNER & $\begin{array}{l}0.23072 * * * \\
(5.1297)\end{array}$ & $\begin{array}{l}0.07594 * * \\
(2.1448)\end{array}$ & $\begin{array}{l}0.16163 * * \\
(2.2542)\end{array}$ & $\begin{array}{l}0.00217 \\
(0.14047)\end{array}$ & $\begin{array}{l}-0.01047 \\
(-1.2574)\end{array}$ & $\begin{array}{l}-0.00188 \\
(-0.42507)\end{array}$ & $\begin{array}{l}-0.03648 \\
(-0.42597)\end{array}$ & $\begin{array}{l}0.05451 * \\
(1.8207)\end{array}$ & $\begin{array}{l}-1.5238 \\
(-0.01204)\end{array}$ & $\begin{array}{l}-86.773 * * \\
(-2.3025)\end{array}$ & $\begin{array}{l}69.1702 \\
(0.58984)\end{array}$ & $\begin{array}{l}-95.079 * \\
(-1.4945)\end{array}$ \\
\hline LERNER_SQ & $\begin{array}{l}-0.35738 \\
(-3.2456)\end{array}$ & & $\begin{array}{l}-0.30598 \\
(-2.0838)\end{array}$ & & $\begin{array}{l}0.01686 \\
(1.5818)\end{array}$ & & $\begin{array}{l}0.17549 \\
(1.3207)\end{array}$ & & $\begin{array}{l}-163.47 \\
(-0.83739)\end{array}$ & & $\begin{array}{l}-315.425 \\
(-1.0305)\end{array}$ & \\
\hline$D E P O$ & $\begin{array}{l}-0.17697 \text { *** } \\
(-9.7056)\end{array}$ & $\begin{array}{l}-0.16306 * * * \\
(-9.9025)\end{array}$ & $\begin{array}{l}-0.06448 * * * \\
(-8.9314)\end{array}$ & $\begin{array}{l}-0.06027^{* * *} \\
(-13.687)\end{array}$ & $\begin{array}{l}0.00438^{*} \\
(1.44601)\end{array}$ & $\begin{array}{l}0.00426 * \\
(1.8219)\end{array}$ & $\begin{array}{l}0.02801 \\
(1.0298)\end{array}$ & $\begin{array}{l}0.02935^{* * * *} \\
(4.8804)\end{array}$ & $\begin{array}{l}-8.1769 \\
(-0.20511)\end{array}$ & $\begin{array}{l}-7.7557 \\
(-0.42143)\end{array}$ & $\begin{array}{l}6.735 \\
(0.99648)\end{array}$ & $\begin{array}{l}3.9859 \\
(0.88062)\end{array}$ \\
\hline$L O A N$ & $\begin{array}{l}-0.22033 * * * \\
(-5.5628)\end{array}$ & $\begin{array}{l}-0.21739 * * * \\
(-7.5151)\end{array}$ & $\begin{array}{l}-0.02506 * * * \\
(-12.259)\end{array}$ & $\begin{array}{l}-0.03983 * * * \\
(-5.2298)\end{array}$ & $\begin{array}{l}0.00382 \\
(0.85639)\end{array}$ & $\begin{array}{l}0.00508^{*} \\
(1.8733)\end{array}$ & $\begin{array}{l}-0.02096 \\
(-0.64373)\end{array}$ & $\begin{array}{l}-0.01023 * * \\
(-2.2428)\end{array}$ & $\begin{array}{l}-37.658 \\
(-0.77249)\end{array}$ & $\begin{array}{l}-50.427 \\
(-1.145)\end{array}$ & $\begin{array}{l}-9.6142 \\
(-0.97742)\end{array}$ & $\begin{array}{l}-28.979 \\
(-0.9962)\end{array}$ \\
\hline$L L P$ & $\begin{array}{l}-0.30159 \\
(-1.1227)\end{array}$ & $\begin{array}{l}-0.09641 \\
(-0.56101)\end{array}$ & $\begin{array}{l}-0.26402 * * * \\
(-5.7377)\end{array}$ & $\begin{array}{l}-0.12018 * * * \\
(-4.1076)\end{array}$ & $\begin{array}{l}0.04856 * * * \\
(1.2428)\end{array}$ & $\begin{array}{l}0.04091 * * * \\
(4.0031)\end{array}$ & $\begin{array}{l}0.38361 * * * \\
(2.9181)\end{array}$ & $\begin{array}{l}0.30631 \\
(1.3839)\end{array}$ & $\begin{array}{l}-273.85 \\
(-1.4049)\end{array}$ & $\begin{array}{l}-200.44 * * * \\
(-6.2084)\end{array}$ & $\begin{array}{l}-399.23 * * * \\
(-4.0919)\end{array}$ & $\begin{array}{l}-263.99 * * * \\
(-33.207)\end{array}$ \\
\hline OVERHEAD & $\begin{array}{l}0.27433 \\
(0.50714)\end{array}$ & $\begin{array}{l}0.81341^{*} \\
(1.6827)\end{array}$ & $\begin{array}{l}1.0609 * * * \\
(2.9646)\end{array}$ & $\begin{array}{l}1.5423 * * * \\
(4.2294)\end{array}$ & $\begin{array}{l}0.11359 * * * \\
(1.6149)\end{array}$ & $\begin{array}{l}0.07947 * * * \\
(2.6528)\end{array}$ & $\begin{array}{l}1.4655^{* * * *} \\
(3.3303)\end{array}$ & $\begin{array}{l}1.1063^{* * * *} \\
(3.5185)\end{array}$ & $\begin{array}{l}-956.12 \\
(-1.4679)\end{array}$ & $\begin{array}{l}-621.08 * * * \\
(-3.1302)\end{array}$ & $\begin{array}{l}-612.11^{*} \\
(-1.8972)\end{array}$ & $\begin{array}{l}41.879 \\
(0.23033)\end{array}$ \\
\hline SIZE & $\begin{array}{l}-0.05591 * * \\
(-2.4321)\end{array}$ & $\begin{array}{l}-0.04559 \text { *** } \\
(-3.5616)\end{array}$ & $\begin{array}{l}-0.03166 \\
(-1.4421)\end{array}$ & $\begin{array}{l}-0.02289^{*} \\
(-1.8748)\end{array}$ & $\begin{array}{l}0.000131 \\
(0.10856)\end{array}$ & $\begin{array}{l}-0.00045 \\
(-0.55676)\end{array}$ & $\begin{array}{l}0.00892 \\
(0.86943)\end{array}$ & $\begin{array}{l}0.00353 \\
(1.4008)\end{array}$ & $\begin{array}{l}-13.354 \\
(-0.85847)\end{array}$ & $\begin{array}{l}-7.6367 * * * \\
(-3.6017)\end{array}$ & $\begin{array}{l}12.206 \\
(0.78316)\end{array}$ & $\begin{array}{l}22.274 * \\
(1.8159)\end{array}$ \\
\hline FOREXG & $\begin{array}{l}0.00283 \\
(0.12478)\end{array}$ & $\begin{array}{l}0.00995 * \\
(1.9114)\end{array}$ & $\begin{array}{l}-0.00303 \\
(-0.33566)\end{array}$ & $\begin{array}{l}-0.00173 \\
(-0.27199)\end{array}$ & $\begin{array}{l}0.00068 \\
(1.0132)\end{array}$ & $\begin{array}{l}0.00058 \\
(0.9678)\end{array}$ & $\begin{array}{l}0.00552 \\
(0.79333)\end{array}$ & $\begin{array}{l}0.0044 \\
(0.99981)\end{array}$ & $\begin{array}{l}0.97656 \\
(0.09528)\end{array}$ & $\begin{array}{l}1.9086 \\
(0.57795)\end{array}$ & $\begin{array}{l}-6.2239 \\
(-0.67814)\end{array}$ & $\begin{array}{l}-4.1396 \\
(-0.62283)\end{array}$ \\
\hline$G D P G$ & $\begin{array}{l}-0.13758 \\
(-0.77936)\end{array}$ & $\begin{array}{l}0.05565 \\
(0.35826)\end{array}$ & $\begin{array}{l}0.04677 \\
(0.41596)\end{array}$ & $\begin{array}{l}0.24758^{* * * *} \\
(3.5365)\end{array}$ & $\begin{array}{l}-0.01401 \\
(-1.0215)\end{array}$ & $\begin{array}{l}-0.02598 * * \\
(-2.3411)\end{array}$ & $\begin{array}{l}0.00101 \\
(0.00627)\end{array}$ & $\begin{array}{l}-0.12924 \\
(-0.80418)\end{array}$ & $\begin{array}{l}188.78 \\
(0.80102)\end{array}$ & $\begin{array}{l}305.84 * * \\
(2.2844)\end{array}$ & $\begin{array}{l}12.491 \\
(0.10346)\end{array}$ & $\begin{array}{l}252.11 * * * \\
(2.6639)\end{array}$ \\
\hline$I N F$ & $\begin{array}{l}0.01399 \\
(0.38483)\end{array}$ & $\begin{array}{l}0.03816 \\
(0.95691)\end{array}$ & $\begin{array}{l}0.01835 \\
(1.1014)\end{array}$ & $\begin{array}{l}0.03091^{*} \\
(1.8774)\end{array}$ & $\begin{array}{l}-0.00259 \\
(-1.6171)\end{array}$ & $\begin{array}{l}-0.00322 \\
(-1.6098)\end{array}$ & $\begin{array}{l}-0.03092 \\
(-1.3155)\end{array}$ & $\begin{array}{l}-0.03753 \text { *** } \\
(-3.5793)\end{array}$ & $\begin{array}{l}99.907 * * * \\
(2.8653)\end{array}$ & $\begin{array}{l}105.85^{* * * *} \\
(3.5031)\end{array}$ & $\begin{array}{l}33.595 * * * \\
(2.6231)\end{array}$ & $\begin{array}{l}46.058^{* * *} \\
(5.6889)\end{array}$ \\
\hline R-square & 0.81 & 0.86 & 0.85 & 0.89 & 0.74 & 0.76 & 0.44 & 0.52 & 0.26 & 0.29 & 0.14 & 0.25 \\
\hline F-statistic & $14.711 * * *$ & $14.509 * * *$ & $21.548 * * *$ & $21.139 * * *$ & $8.346^{* * * *}$ & $8.341^{* * *}$ & $3.622 * * *$ & $3.618^{* * *}$ & $1.978 * * *$ & $1.983 * * *$ & $1.865 * * *$ & $1.856^{* * *}$ \\
\hline VIF test & 9.45 & 9.29 & 5.91 & 6.37 & 6.70 & 7.42 & 3.19 & 3.68 & 2.39 & 2.52 & 2.08 & 2.39 \\
\hline Number of Observation & 721 & 721 & 868 & 868 & 846 & 846 & 834 & 834 & 837 & 837 & 821 & 821 \\
\hline
\end{tabular}


Table 8. The role of too-big-to-fail subsidies for overall period. This table examines the influence of systematic size of banking on the competition-stability nexus for overall period. $L E R N E R$ is the market power index. EQTA is the ratio of total equity to total assets. CAR is the total risk-based capital ratio. SDROA (SDROE) is the standard deviation of return on assets (equity) calculated from a three-period based rolling window. ZROA (ZROE) is the Z-score index based on ROA (ROE). DEPO is the ratio of total deposits to total assets. $L O A N$ is the ratio of total loans to total assets. $L L P$ is the ratio of loan loss provisions to total loans. OVERHEAD is the ratio of operating expenses to total assets. SIZE is the logarithm of total assets. FOREXG is the growth of foreign exchange reserves. GDPG is the growth rate of real gross domestic product $(G D P)$. INF is the inflation rate. TBTS is the ratio of three largest banks' total assets to GDP. A constant is included but not reported. The model is estimated using the 2 SLS method with cross-section and time fixed-effect corrections. Instrumental variables for $L E R N E R$ consist of ECOFREE (economic freedom), RLAW (rule of law) and STOCK (the ratio of stock market capitalization to GDP). The $t$-statistic values are in parentheses. (***) indicates significance at the $1 \%$ level, while $(* *)$ and $(*)$ indicate significance at the $5 \%$ and $10 \%$ levels, respectively. Muticollinearity problems exist if VIF test exceeds 10 basis points.

\begin{tabular}{|c|c|c|c|c|c|c|}
\hline Explanatory variables & $C A R$ & $E Q T A$ & SDROA & SDROE & ZROA & ZROE \\
\hline LERNER & $\begin{array}{l}0.15873^{* * *} \\
(4.7671)\end{array}$ & $\begin{array}{l}0.06604 * * * \\
(4.1138)\end{array}$ & $\begin{array}{l}0.02211 * * * \\
(2.6504)\end{array}$ & $\begin{array}{l}0.06096 * * * \\
(2.6061)\end{array}$ & $\begin{array}{l}-13.7445^{*} \\
(-0.69552)\end{array}$ & $\begin{array}{l}22.152 \\
(0.52431)\end{array}$ \\
\hline LERNER*TBTS & $\begin{array}{l}-0.17963 * * * \\
(-4.7553)\end{array}$ & $\begin{array}{l}-0.08155^{* * * *} \\
(-2.9457)\end{array}$ & $\begin{array}{l}-0.03606 * * \\
(-2.452)\end{array}$ & $\begin{array}{l}-0.13561 * * * \\
(-3.476)\end{array}$ & $\begin{array}{l}-22.758 \\
(-0.62876)\end{array}$ & $\begin{array}{l}-29.268 \\
(-0.41864)\end{array}$ \\
\hline$D E P O$ & $\begin{array}{l}-0.13228 * * * \\
(-9.2744)\end{array}$ & $\begin{array}{l}-0.14962 * * * \\
(-20.997)\end{array}$ & $\begin{array}{l}-0.000589 \\
(-0.15242)\end{array}$ & $\begin{array}{l}0.03559^{* * *} \\
(3.4071)\end{array}$ & $\begin{array}{l}-32.712 * * * \\
(-3.6952)\end{array}$ & $\begin{array}{l}-25.769 * * \\
(-2.2855)\end{array}$ \\
\hline$L O A N$ & $\begin{array}{l}-0.16281 * * * \\
(-10.142)\end{array}$ & $\begin{array}{l}0.00223 \\
(0.29779)\end{array}$ & $\begin{array}{l}-0.02746 * * * \\
(-6.5721)\end{array}$ & $\begin{array}{l}-0.03992 * * * \\
(-3.4924)\end{array}$ & $\begin{array}{l}19.587 * * \\
(1.9717)\end{array}$ & $\begin{array}{l}26.847 * * * \\
(3.4727)\end{array}$ \\
\hline$L L P$ & $\begin{array}{l}-0.12157 * * \\
(-2.4229)\end{array}$ & $\begin{array}{l}-0.17958 * * * \\
(-6.8463)\end{array}$ & $\begin{array}{l}0.13831 * * * \\
(10.221)\end{array}$ & $\begin{array}{l}0.03249 \\
(0.64965)\end{array}$ & $\begin{array}{l}-22.168 \\
(-0.80108)\end{array}$ & $\begin{array}{l}-23.546 \\
(-0.35727)\end{array}$ \\
\hline OVERHEAD & $\begin{array}{l}0.49439 * * * \\
(2.7301)\end{array}$ & $\begin{array}{l}0.74376^{* * * *} \\
(9.4357)\end{array}$ & $\begin{array}{l}0.13693 * * * \\
(2.8634)\end{array}$ & $\begin{array}{l}0.44687 * * * \\
(3.2817)\end{array}$ & $\begin{array}{l}-271.24 * * * \\
(-2.8195)\end{array}$ & $\begin{array}{l}-355.02 * * * \\
(-2.7976)\end{array}$ \\
\hline SIZE & $\begin{array}{l}-0.03811 * * * \\
(-9.1329)\end{array}$ & $\begin{array}{l}-0.03781 * * * \\
(-18.859)\end{array}$ & $\begin{array}{l}-0.000381 \\
(-0.34587)\end{array}$ & $\begin{array}{l}0.00068 \\
(0.23047)\end{array}$ & $\begin{array}{l}2.2208 \\
(0.75392)\end{array}$ & $\begin{array}{l}-4.3351 * * \\
(-2.1694)\end{array}$ \\
\hline FOREXG & $\begin{array}{l}-0.00268 \\
(-0.34451)\end{array}$ & $\begin{array}{l}-0.00358 \\
(-1.1845)\end{array}$ & $\begin{array}{l}0.00004 \\
(0.02501)\end{array}$ & $\begin{array}{l}0.00689 \\
(1.6159)\end{array}$ & $\begin{array}{l}10.671^{* * *} \\
(2.7602)\end{array}$ & $\begin{array}{l}4.4534 \\
(0.83858)\end{array}$ \\
\hline$G D P G$ & $\begin{array}{l}0.15161 * \\
(1.7427)\end{array}$ & $\begin{array}{l}0.08132 \\
(1.6292)\end{array}$ & $\begin{array}{l}-0.00061 \\
(-0.02531)\end{array}$ & $\begin{array}{l}0.05074 \\
(0.80049)\end{array}$ & $\begin{array}{l}32.749 \\
(0.57483)\end{array}$ & $\begin{array}{l}72.285 \\
(0.70195)\end{array}$ \\
\hline$I N F$ & $\begin{array}{l}-0.02343 \\
(-0.52902)\end{array}$ & $\begin{array}{l}0.00936 \\
(0.42414)\end{array}$ & $\begin{array}{l}0.02173 * \\
(1.9003)\end{array}$ & $\begin{array}{l}0.01963 \\
(0.6359)\end{array}$ & $\begin{array}{l}-12.059 \\
(-0.44426)\end{array}$ & $\begin{array}{l}-11.501 \\
(-0.41351)\end{array}$ \\
\hline TBTS & $\begin{array}{l}0.01781 \\
(-4.7553)\end{array}$ & $\begin{array}{l}0.04441 \text { *** } \\
(5.2106)\end{array}$ & $\begin{array}{l}0.02643 * * * \\
(5.6628)\end{array}$ & $\begin{array}{l}0.06461 * * * \\
(5.0792)\end{array}$ & $\begin{array}{l}-25.088 * * \\
(-2.1391)\end{array}$ & $\begin{array}{l}-47.051 * * * \\
(-3.2823)\end{array}$ \\
\hline R-square & 0.68 & 0.76 & 0.34 & 0.26 & 0.21 & 0.16 \\
\hline F-statistic & $14.582 * * *$ & $23.369 * * *$ & $5.081 * * *$ & $3.973 * * *$ & $2.748 * * *$ & $2.211 * * *$ \\
\hline VIF test & 3.86 & 5.09 & 1.84 & 1.63 & 1.49 & 1.42 \\
\hline Number of Observation & 2826 & 4220 & 3994 & 3852 & 3901 & 3774 \\
\hline
\end{tabular}


Table 9. The Asian crisis and too-big-to fail subsidies. The influence of systematic size of banking on the competition-stability nexus over the 1997-1999 period. LERNER is the market power index. EQTA is the ratio of total equity to total assets. CAR is the total risk-based capital ratio. SDROA (SDROE) is the standard deviation of return on assets (equity) calculated from a threeperiod based rolling window. ZROA (ZROE) is the Z-score index based on ROA (ROE). DEPO is the ratio of total deposits to total assets. $L O A N$ is the ratio of total loans to total assets. $L L P$ is the ratio of loan loss provisions to total loans. OVERHEAD is the ratio of operating expenses to total assets. SIZE is the logarithm of total assets. FOREXG is the growth of foreign exchange reserves. $G D P G$ is the growth rate of real gross domestic product $(G D P)$. INF is the inflation rate. TBTS is the ratio of three largest banks' total assets to GDP. A constant is included but not reported. The model is estimated using the 2SLS method with cross-section and time fixed-effect corrections. Instrumental variables for LERNER consist of ECOFREE (economic freedom), $R L A W$ (rule of law) and STOCK (the ratio of stock market capitalization to GDP). The $t$-statistic values are in parentheses. (***) indicates significance at the $1 \%$ level, while $(* *)$ and $(*)$ indicate significance at the $5 \%$ and $10 \%$ levels, respectively. Muticollinearity problems exist if VIF test exceeds 10 basis points.

\begin{tabular}{|c|c|c|c|c|c|c|}
\hline Explanatory variables & $C A R$ & $E Q T A$ & SDROA & SDROE & ZROA & ZROE \\
\hline LERNER & $\begin{array}{l}-0.11305 * * \\
(-2.4069)\end{array}$ & $\begin{array}{l}-0.01413 \\
(-0.44649)\end{array}$ & $\begin{array}{l}-0.01023 * \\
(-0.19222)\end{array}$ & $\begin{array}{l}-0.02626 * * \\
(-2.5404)\end{array}$ & $\begin{array}{l}24.105 * * * \\
(6.2099)\end{array}$ & $\begin{array}{l}59.165^{* * *} \\
(3.689)\end{array}$ \\
\hline LERNER*TBTS & $\begin{array}{l}0.05616 \\
(0.21881)\end{array}$ & $\begin{array}{l}-0.21879 * * * \\
(-4.5208)\end{array}$ & $\begin{array}{l}0.33649 * * * \\
(8.4238)\end{array}$ & $\begin{array}{l}0.0187 \\
(0.14537)\end{array}$ & $\begin{array}{l}68.251 \\
(0.85577)\end{array}$ & $\begin{array}{l}-95.295 \\
(-1.0259)\end{array}$ \\
\hline$D E P O$ & $\begin{array}{l}-0.03346 \\
(-0.42584)\end{array}$ & $\begin{array}{l}-0.1894 * * * \\
(-9.8558)\end{array}$ & $\begin{array}{l}-0.02676 \\
(-0.92299)\end{array}$ & $\begin{array}{l}-0.02859 \\
(-0.87663)\end{array}$ & $\begin{array}{l}-25.861 \\
(-1.0106)\end{array}$ & $\begin{array}{l}-74.856 \\
(-1.3102)\end{array}$ \\
\hline$L O A N$ & $\begin{array}{l}-0.16844 * * * \\
(-3.4209)\end{array}$ & $\begin{array}{l}0.04657 \\
(1.4082)\end{array}$ & $\begin{array}{l}-0.07523 \\
(-1.3521)\end{array}$ & $\begin{array}{l}-0.07778 * * * \\
(-9.9026)\end{array}$ & $\begin{array}{l}29.321 * * \\
(2.4443)\end{array}$ & $\begin{array}{l}89.019 * * * \\
(5.9636)\end{array}$ \\
\hline$L L P$ & $\begin{array}{l}0.28284 \\
(1.4924)\end{array}$ & $\begin{array}{l}0.08296 \\
(1.3793)\end{array}$ & $\begin{array}{l}0.07918 \\
(0.85658)\end{array}$ & $\begin{array}{l}0.00415 \\
(0.08705)\end{array}$ & $\begin{array}{l}-38.157 \\
(-1.5699)\end{array}$ & $\begin{array}{l}-5.0269 \\
(-0.11144)\end{array}$ \\
\hline OVERHEAD & $\begin{array}{l}0.46927 \\
(0.61903)\end{array}$ & $\begin{array}{l}0.11152 \\
(0.28509)\end{array}$ & $\begin{array}{l}0.01812 \\
(0.07634)\end{array}$ & $\begin{array}{l}-0.25461 \\
(-1.2718)\end{array}$ & $\begin{array}{l}-121.794 \\
(-0.64495)\end{array}$ & $\begin{array}{l}647.2 * * * \\
(8.4798)\end{array}$ \\
\hline SIZE & $\begin{array}{l}-0.08002 * * \\
(-2.0639)\end{array}$ & $\begin{array}{l}-0.03133^{* * *} \\
(-4.9906)\end{array}$ & $\begin{array}{l}-0.0515 * * * \\
(-7.3885)\end{array}$ & $\begin{array}{l}-0.06546^{* * *} \\
(-2.9508)\end{array}$ & $\begin{array}{l}4.8601 \\
(0.31528)\end{array}$ & $\begin{array}{l}50.581 * * * \\
(2.6975)\end{array}$ \\
\hline FOREXG & $\begin{array}{l}0.00922 \\
(0.52786)\end{array}$ & $\begin{array}{l}0.01054 * * \\
(2.3453)\end{array}$ & $\begin{array}{l}-0.01315^{* * *} \\
(-3.2231)\end{array}$ & $\begin{array}{l}0.02109 * * * \\
(3.1871)\end{array}$ & $\begin{array}{l}1.8871 \\
(0.53683)\end{array}$ & $\begin{array}{l}-2.3124 \\
(-1.2779)\end{array}$ \\
\hline$G D P G$ & $\begin{array}{l}0.93757 \\
(0.79523)\end{array}$ & $\begin{array}{l}0.56373 \\
(0.91224)\end{array}$ & $\begin{array}{l}-1.1767 \\
(-1.5039)\end{array}$ & $\begin{array}{l}-0.13529 \\
(-0.33993)\end{array}$ & $\begin{array}{l}-643.14 * * * \\
(-5.0017)\end{array}$ & $\begin{array}{l}-282.83 * * * \\
(-4.4134)\end{array}$ \\
\hline$I N F$ & $\begin{array}{l}-2.6819 * * * \\
(-4.5737)\end{array}$ & $\begin{array}{l}-0.31906 \\
(-1.1651)\end{array}$ & $\begin{array}{l}0.05153 \\
(0.22076)\end{array}$ & $\begin{array}{l}-0.28919 \\
(-1.2702)\end{array}$ & $\begin{array}{l}-15.253 \\
(-0.09359)\end{array}$ & $\begin{array}{l}783.08 * * * \\
(3.4252)\end{array}$ \\
\hline TBTS & $\begin{array}{l}-0.18834 \\
(-0.32027)\end{array}$ & $\begin{array}{l}-0.23132 \\
(-1.0389)\end{array}$ & $\begin{array}{l}0.53144 * \\
(1.6925)\end{array}$ & $\begin{array}{l}0.16446 \\
(0.87233)\end{array}$ & $\begin{array}{l}149.71 \\
(0.78535)\end{array}$ & $\begin{array}{l}-13.189 \\
(-0.13575)\end{array}$ \\
\hline R-square & 0.79 & 0.84 & 0.32 & 0.62 & 0.33 & 0.44 \\
\hline F-statistic & $8.665^{* * *}$ & $17.773 * * *$ & $4.018 * * *$ & $4.527 * * *$ & $2.092 * * *$ & $2.732 * * *$ \\
\hline VIF test & 9.32 & 9.17 & 2.65 & 5.01 & 2.86 & 3.63 \\
\hline Number of Observation & 492 & 813 & 807 & 761 & 797 & 747 \\
\hline
\end{tabular}


Table 10. The global credit crisis and too-big-to fail subsidies. The influence of systematic size of banking on the competition-stability nexus over the 2007-2009 period. LERNER is the market power index. EQTA is the ratio of total equity to total assets. CAR is the total risk-based capital ratio. SDROA (SDROE) is the standard deviation of return on assets (equity) calculated from a three-period based rolling window. ZROA (ZROE) is the Z-score index based on ROA (ROE). DEPO is the ratio of total deposits to total assets. $L O A N$ is the ratio of total loans to total assets. $L L P$ is the ratio of loan loss provisions to total loans. OVERHEAD is the ratio of operating expenses to total assets. SIZE is the logarithm of total assets. FOREXG is the growth of foreign exchange reserves. GDPG is the growth rate of real gross domestic product $(G D P)$. INF is the inflation rate. TBTS is the ratio of three largest banks' total assets to GDP. A constant is included but not reported. The model is estimated using the 2SLS method with cross-section and time fixed-effect corrections. Instrumental variables for LERNER consist of ECOFREE (economic freedom), RLAW (rule of law) and STOCK (the ratio of stock market capitalization to GDP). The $t$-statistic values are in parentheses. (***) indicates significance at the $1 \%$ level, while (**) and (*) indicate significance at the $5 \%$ and $10 \%$ levels, respectively. Muticollinearity problems exist if VIF test exceeds 10 basis points.

\begin{tabular}{|c|c|c|c|c|c|c|}
\hline Explanatory variables & $C A R$ & $E Q T A$ & SDROA & SDROE & $Z R O A$ & $Z R O E$ \\
\hline LERNER & $\begin{array}{l}-0.02208 \\
(-0.04919)\end{array}$ & $\begin{array}{l}-0.25941 \\
(-1.3867)\end{array}$ & $\begin{array}{l}0.02532 \\
(1.0109)\end{array}$ & $\begin{array}{l}0.39182^{*} \\
(1.5504)\end{array}$ & $\begin{array}{l}-474.79 * \\
(-1.2058)\end{array}$ & $\begin{array}{l}-642.088^{*} \\
(-1.5111)\end{array}$ \\
\hline LERNER*TBTS & $\begin{array}{l}0.14692 \\
(0.23015)\end{array}$ & $\begin{array}{l}0.50541^{*} \\
(1.8566)\end{array}$ & $\begin{array}{l}-0.04767 \\
(-1.3188)\end{array}$ & $\begin{array}{l}-0.66839 * \\
(-1.8402)\end{array}$ & $\begin{array}{l}781.72 \\
(1.3598)\end{array}$ & $\begin{array}{l}1080.94 * \\
(1.7812)\end{array}$ \\
\hline$D E P O$ & $\begin{array}{l}-0.12593 * * * \\
(-4.8943)\end{array}$ & $\begin{array}{l}-0.06001 * * * \\
(-2.7439)\end{array}$ & $\begin{array}{l}0.00385 \\
(1.3283)\end{array}$ & $\begin{array}{l}0.03169 \\
(1.0676)\end{array}$ & $\begin{array}{l}6.9164 \\
(0.15608)\end{array}$ & $\begin{array}{l}1.1599 \\
(0.02375)\end{array}$ \\
\hline$L O A N$ & $\begin{array}{l}-0.13913 \\
(-1.5012)\end{array}$ & $\begin{array}{l}0.01689 \\
(0.64076)\end{array}$ & $\begin{array}{l}0.00361 \\
(1.0053)\end{array}$ & $\begin{array}{l}-0.02898 \\
(-0.79339)\end{array}$ & $\begin{array}{l}-14.763 \\
(-0.26823)\end{array}$ & $\begin{array}{l}51.592 \\
(0.81968)\end{array}$ \\
\hline$L L P$ & $\begin{array}{l}-0.10334 \\
(-0.73781)\end{array}$ & $\begin{array}{l}-0.05478 \\
(-0.61102)\end{array}$ & $\begin{array}{l}0.03859 * * * \\
(3.2629)\end{array}$ & $\begin{array}{l}0.23854 * * \\
(1.9902)\end{array}$ & $\begin{array}{l}-125.71 \\
(-0.69456)\end{array}$ & $\begin{array}{l}-72.503 \\
(-0.34092)\end{array}$ \\
\hline OVERHEAD & $\begin{array}{l}-0.42131 \\
(-0.51268)\end{array}$ & $\begin{array}{l}0.09585 \\
(0.25853)\end{array}$ & $\begin{array}{l}0.13119^{* *} \\
(2.5842)\end{array}$ & $\begin{array}{l}1.7879 * * * \\
(3.5109)\end{array}$ & $\begin{array}{l}-1515.33^{*} \\
(-1.9452)\end{array}$ & $\begin{array}{l}-1174.52 \\
(-1.3507)\end{array}$ \\
\hline SIZE & $\begin{array}{l}-0.05702 * * * \\
(-4.7408)\end{array}$ & $\begin{array}{l}-0.06338^{* * *} \\
(-7.1775)\end{array}$ & $\begin{array}{l}0.00084 \\
(0.70333)\end{array}$ & $\begin{array}{l}0.02692 * * \\
(2.2114)\end{array}$ & $\begin{array}{l}-40.629 * * \\
(-2.2296)\end{array}$ & $\begin{array}{l}-10.181 \\
(-0.49035)\end{array}$ \\
\hline FOREXG & $\begin{array}{l}-0.0021 \\
(-0.28906)\end{array}$ & $\begin{array}{l}-0.00058 \\
(-0.08039)\end{array}$ & $\begin{array}{l}0.00086 \\
(0.89516)\end{array}$ & $\begin{array}{l}0.00167 \\
(0.17039)\end{array}$ & $\begin{array}{l}0.65933 \\
(0.04494)\end{array}$ & $\begin{array}{l}3.6167 \\
(0.22426)\end{array}$ \\
\hline$G D P G$ & $\begin{array}{l}0.10504 \\
(0.21156)\end{array}$ & $\begin{array}{l}0.54185^{* *} \\
(2.4112)\end{array}$ & $\begin{array}{l}-0.0651 * * \\
(-2.1986)\end{array}$ & $\begin{array}{l}-0.69073 * * \\
(-2.3098)\end{array}$ & $\begin{array}{l}908.22 * \\
(1.9507)\end{array}$ & $\begin{array}{l}1107.89 * * \\
(2.2384)\end{array}$ \\
\hline$I N F$ & $\begin{array}{l}0.15375 \\
(0.90258)\end{array}$ & $\begin{array}{l}0.03486 \\
(0.43107)\end{array}$ & $\begin{array}{l}-0.01717 \\
(-1.6062)\end{array}$ & $\begin{array}{l}-0.19436^{*} \\
(-1.7929)\end{array}$ & $\begin{array}{l}279.99 * \\
(1.6826)\end{array}$ & $\begin{array}{l}235.88 \\
(1.3152)\end{array}$ \\
\hline$T B T S$ & $\begin{array}{l}-0.13632 \\
(-0.16535)\end{array}$ & $\begin{array}{l}-0.72547 * \\
(-2.1256)\end{array}$ & $\begin{array}{l}0.07362 \\
(1.6157)\end{array}$ & $\begin{array}{l}1.1269 * * \\
(2.449)\end{array}$ & $\begin{array}{l}-1252.16^{*} \\
(-1.7125)\end{array}$ & $\begin{array}{l}-1749.8 * * \\
(-2.2623)\end{array}$ \\
\hline R-square & 0.87 & 0.88 & 0.73 & 0.49 & 0.26 & 0.12 \\
\hline F-statistic & $16.636^{* * *}$ & $23.869 * * *$ & $8.476^{* * *}$ & $3.966 * * *$ & $2.165^{* * *}$ & $1.731 * * *$ \\
\hline VIF test & 2.78 & 5.65 & 7.13 & 3.70 & 2.51 & 2.43 \\
\hline Number of Observation & 721 & 868 & 846 & 834 & 837 & 821 \\
\hline
\end{tabular}

